January 2020

\title{
The Next "Big Short": COVID-19, Student Loan Discharge in Bankruptcy, and the SLABS Market
}

Samantha L. Bailey

Roger Williams University School of Law

Christopher J. Ryan Jr.

Roger Williams University School of Law

\section{Recommended Citation}

Samantha L. Bailey \& Christopher J Ryan, The Next "Big Short": COVID-19, Student Loan Discharge in Bankruptcy, and the SLABS Market, 73 SMU L. REV. 809 (2020)

https://scholar.smu.edu/smulr/vol73/iss4/4

This Article is brought to you for free and open access by the Law Journals at SMU Scholar. It has been accepted for inclusion in SMU Law Review by an authorized administrator of SMU Scholar. For more information, please visit http://digitalrepository.smu.edu. 


\title{
The NeXt "Big Short": COVID-19, STUDENT LOAN DisCHARGE IN BANKRUPTCY, AND THE SLABS MARKET
}

\author{
Samantha L. Bailey \& Christopher J. Ryan, Jr.*
}

\begin{abstract}
Even before the spread of the COVID-19 pandemic, student loan debttotaling over $\$ 1.64$ trillion-was a cause for concern, as it is the second largest source of consumer debt in the United States, trailing only mortgage debt. And like collateralized mortgage debt, there is a market for collateralized student debt. Student loan asset-backed securities (SLABS) are the securitized form of student loan debt, repackaged as a marketable financial instrument. As with any investment vehicle, asset-backed securities like $S L A B S$ come with risk, particularly when borrowers default on their loans or have their debt discharged through bankruptcy proceedings. However, historically, SLABS have been a relatively sure bet-yielding consistent returns on investment-given that many student loans are guaranteed by the government and that student loan debt obligations are difficult for borrowers to escape. This is because there has been a long-standing and near-total prohibition on student loan discharge via bankruptcy proceedings. A spate of recent decisions rendered in the United States Bankruptcy Courts and two federal circuit courts of appeal could eliminate that prohibition. In turn, this decision could negatively impact the SLABS market, and in a broader sense, the United States economy.

This Article addresses this possibility, especially in light of the fact that rising unemployment in the wake of the COVID-19 crisis is sure to increase the rate of default on student loans. Part II of this Article describes the present student loan crisis in terms of available statistics and common student loan repayment programs. Next, Part III chronicles the development and operation of bankruptcy law in the context of student loans. Part III also explains the general unwillingness to discharge student loans in

* Co-authors, listed alphabetically. Samantha Bailey is a Candidate for Juris Doctor (2021) at the Roger Williams University School of Law. CJ Ryan is an Associate Professor of Law at the Roger Williams University School of Law and an Affiliated Scholar at the American Bar Foundation. We would like to thank Matt Brucker, Howard University School of Law, and John Chung, Roger Williams University School of Law, for their incredibly helpful comments on an earlier draft of this Article. In addition, we would like to thank Erin Ferry, Candidate for Juris Doctor (2021), Roger Williams University School of Law, for her assistance in formatting the many citations listed in the footnotes of this Article.
\end{abstract}


bankruptcy proceedings via the Brunner test. Part IV focuses on student loan asset-backed securities: what they are, how they operate, and how they generate profit. This final section draws the connection between student loan discharge via bankruptcy and its potential impacts on the SLABS market and the economy at large. This Article concludes with observations about how the current crisis levels of student loan debt, when combined with rising unemployment and recent bankruptcy court decisions, could impact the stability of the SLABS market and the broader economy.

\section{TABLE OF CONTENTS}

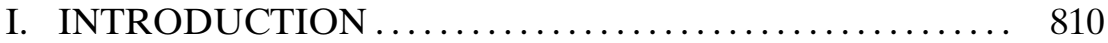

II. STUDENT LOANS IN CONTEXT ................ 810

A. Trillions of Reasons ...................... 814

B. Student Loan Repayment ..................... 816

1. Never-Ending Interest ................... 819

2. Student Loan Forgiveness and the "Tax Bomb".... 820

C. Inability to Meet Repayment Obligations ....... 822

1. Forbearance and Deferment: Short-Term Solutions . 822

2. Default: The "End of the Road"............... 823

III. SQUARING STUDENT LOANS WITH BANKRUPTCY PRINCIPLES ................................. 825

A. How Bankruptcy Law Operates in the Context of STUdent LoAns ........................... 825

1. When Does an "Undue Hardship" Exist? ........ 826

2. The Brunner Test ........................... 828

B. The Practical Prohibition Against Student Loan Discharge via Bankruptcy .............. 830

1. The First Crack in the Brunner Test's Armor ...... 832

2. Application of the Brunner Test in Rosenberg v. New York State Higher Education Services Corp. . 833

IV. STUDENT LOAN ASSET-BACKED SECURITIES .... 836

A. SLABS: A Foundation in Mortgage-Backed SECURITIES .............................. 836

B. A Low-Risk Investment? ................... 839

V. CONCLUSION ............................... 844

\section{INTRODUCTION}

$\mathrm{I}$

F the title of this Article sounds familiar, it is probably because you have heard it before. In finance, short-selling-or "shorting"-a stock refers to an investor borrowing stock shares to sell in the hope that the shares can be purchased later at a lower price. These shares are then returned to the shareholding lender, and the investor can profit from 
the difference between the sale price and the purchase price. ${ }^{1}$ In other words, a "short" is a bet by the investor that the stock will decrease in value, the shareholder will be no worse off in terms of shares held, and the investor will gain from the sell-off. ${ }^{2}$ Film director Adam McKay's The Big Short-and the Michael Lewis book of the same name-chronicles the lives of financiers prior to the "Great Recession" of 2008. ${ }^{3}$ These financiers, including physician-turned-hedge-fund-manager Michael Burry, spotted the "housing bubble" before most other investors and predicted the impending market collapse that resulted from the subprime mortgage crisis. ${ }^{4}$ They did so by spotting patterns: Mortgage originators issued loans to subprime borrowers so that the loans could be bundled and sold to firms that securitized the mortgage loans. ${ }^{5}$ The securitized loans were then packaged into tranches by credit risk, through dubious rating practices, and offered to investors as mortgage-backed securities and synthetic collateralized debt obligations (CDOs). ${ }^{6}$ These mortgage-backed securities and CDOs amplified investor risk, given the increased exposure to underlying assets that were themselves dangerous gambles. ${ }^{7}$ Thus, these hedge fund managers devised a plan to short the riskiest tranches of the mortgage-backed securities through credit swaps, since these securities would become profitable when the market ultimately collapsed. ${ }^{8}$ Effectively, they bet against the big banks, which issued mortgage-backed securities as investment vehicles in the securities market, as well as the American economy. Their prediction proved to be lucrative, as the economy indeed stalled for several years after the housing bubble burst.

We recognize that the first part of the title of this Article suggests that this Article has something to do with shorting mortgage bonds. We do not mean to mislead you, dear reader, but this Article is not about shorting

1. See, e.g., Joshua Kennon, The Basics of Shorting Stock: A Beginner's Guide for How to Short Stocks, BALANCE (May 27, 2020), https://www.thebalance.com/the-basics-ofshorting-stock-356327 [https://perma.cc/4PG3-3QTT] (discussing how stocks are shortsold).

2. See, e.g., Philip van Doorn, Why You Should Never Short-Sell Stocks, MARKETWATCH (Nov. 27, 2015, 9:16 AM), https://www.marketwatch.com/story/why-youshould-never-short-sell-stocks-2015-11-19 [https://perma.cc/6D5T-26SM] (defining shortselling securities).

3. See, e.g., Jon Hartley, 'The Big Short' Shines a Light on the Financial Crisis with Good Humor, Forbes (Nov. 29, 2015, 4:00 PM), https://www.forbes.com/sites/jonhartley/ 2015/11/29/the-big-short-shines-a-light-on-the-financial-crisis-with-good-humor/\#12c74c23 67d6[https://perma.cc/VVC3-ADAY].

4. Michael Lewis, Betting on the Blind Side, VANity FAIR (Mar. 1, 2010), https:// www.vanityfair.com/news/2010/04/wall-street-excerpt-201004 [https://perma.cc/PCL3FNQ9].

5. What Role Did Securitization Play in the Global Financial Crisis?, Investopedia (June 30, 2020), https://www.investopedia.com/ask/answers/041515/what-role-did-securitiza tion-play-us-subprime-mortgage-crisis.asp [https://perma.cc/WK32-G2JQ].

6. James Chen, Synthetic Collateralized Debt Obligation (CDO), InvestopediA (Mar. 30, 2020), https://www.investopedia.com/terms/s/syntheticcdo.asp [https://perma.cc/ XV65-Y9ZZ] (noting the role that synthetic CDOs played in the subprime mortgage crisis).

7. $I d$.

8. Id.; Lewis, supra note 4. 
securities or even explicitly about mortgage-backed securities. However, the financial crisis in the 2008 recession is relevant as a corollary to the topic of this Article, especially because we are now in the midst of one of the greatest periods of economic uncertainty in history. ${ }^{9}$ Mortgagebacked securities are once again in a cycle of negative convexity as interest rates continue to fall, and the prices of these bonds fall along with them..$^{10}$ But mortgage debt is just one of the many consumer-debt sectors afflicted by the financial implications of the global COVID-19 pandemic. After mortgage debt, student-loan debt is the largest source of consumer debt in the United States. ${ }^{11}$ Like mortgage-backed securities, student loan asset-backed securities (SLABS) are the securitized form of student loan debt, repackaged as a marketable financial instrument. ${ }^{12}$ Traditional lenders, including Sallie Mae, and those newer to the scene, such as SoFi, bundle student loans and securitize them in the same way that mortgagebacked securities and other collateralized debt obligations are issued to investors. ${ }^{13}$ Like mortgage-backed securities, SLABS are backed by income streams generated by student loan payments made by individual borrowers. ${ }^{14}$ As with any investment vehicle, SLABS come with risk, par-

9. See, e.g., Scott R. Baker, Nicholas Bloom, Stephen J. Davis \& Stephen J. Terry, COVID-Induced Economic Uncertainty (Nat'l Bureau of Econ. Rsch., Working Paper No. 26983, 2020), https://www.nber.org/papers/w26983 [https://perma.cc/ULA9-WNUE] (analyzing the impact of stock market volatility, newspaper-based economic uncertainty, and subjective uncertainty in business expectation surveys on the economy).

10. See, e.g., Mark Kolakowski, Mortgage-Backed Bonds That Spurred 2008 Crisis Are in Trouble Again, Investopedia (Sept. 16, 2019), https://www.investopedia.com/whymortgage-backed-bonds-that-spurred-2008-crisis-are-in-trouble-again-4770040 [https:// perma.cc/VK9U-HW9K].

11. Matt Egan, Americans Now Have a Record \$14 Trillion in Debt, CNN Bus. (Nov. 13, 2019), https://www.cnn.com/2019/11/13/business/household-debt-student-loans-fed/index.html [https://perma.cc/6PBH-KJN9]. This is not a new occurrence; student loan debt has occupied the second largest share of consumer debt for several years. See Student Loan Debt by Age Group, Fed. RsRv. Bank N.Y. (Mar. 29, 2013), https://www.newyorkfed.org/ studentloandebt/index.html [https://perma.cc/9HNB-2NVV] (noting that student loan debt eclipsed both auto loans and credit card debt in 2012 and has held fast as the second largest sector of consumer debt ever since); see also Zack Friedman, Student Loan Debt Statistics in 2020: A Record \$1.6 Trillion, Forbes (Feb. 3, 2020, 6:51 PM), https://www.forbes.com/ sites/zackfriedman/2020/02/03/student-loan-debt-statistics/\#42ab3b38281f [https://perma.cc/ W8F8-B547].

12. Jack Du, Student Loan Asset-Backed Securities: Safe or Subprime?, InVESTOPEDIA (Apr. 22, 2020), https://www.investopedia.com/articles/investing/081815/student-loan-asset backed-securities-safe-or-subprime.asp [https://perma.cc/NF2K-548S].

13. See Tom Arnold, Bonnie G. Buchanan \& J. Fiona Robertson, The Economics of Sallie Mae, 18 J. Structured Fin. 65 (2012). See generally Francesco Pizzini, SLABSThe Student Loan Securitization Market in the US, ResearchGate 18-19 (Mar. 2019), https://www.researchgate.net/publication/332514418 [https://perma.cc/P82P-SKGG]. For a discussion of recent SLABS issuances by big lenders and newer lenders, see Glen Fest, Sallie Mae Launches \$433M SLABS Issuance, Asset SECURITIZATION ReP. (Jan. 30, 2020), https://asreport.americanbanker.com/news/sallie-mae-launches-433m-slabs-issuance [https://perma.cc/KAC7-8CTZ], and see also Glen Fest, SoFi Launches \$1B Refi SLABS Deal, the Lender's Largest to Date, Asset Securitization Rep. (Feb. 19, 2020), https:// asreport.amricanbanker.com/news/sofi-launches-1b-refi-slabs-deal-the-lenders-largest-todate [https://perma.cc/V87H-H3S3].

14. Both SLABS and mortgage-backed securities rely on income streams derived from borrowers repaying their loans. However, mortgage-backed securities have the benefit of the borrower putting up the underlying collateral-for example, a house-while SLABS 
ticularly when borrowers default on their loans or have their debt discharged through bankruptcy proceedings, and are rated by credit rating agencies to evidence the level of risk they carry. ${ }^{15}$ However, student loan debt has historically been a relatively sure bet-yielding consistent returns on investment-given the presumption that student loans are guaranteed by the government and student loan debt obligations are difficult for borrowers to escape. ${ }^{16}$ This is because there has been a long-standing and near-total prohibition on student loan discharge via bankruptcy. ${ }^{17}$ Three recent decisions-one rendered by the Chief Judge of the United States Bankruptcy Court for the Southern District of New York and two rendered by separate three-judge panels of the United States Court of Appeals for the Fifth Circuit and the Tenth Circuit, respectively-could eliminate that virtual prohibition. In turn, these decisions, and the negative economic effects of the COVID-19 pandemic, could negatively impact the SLABS market, and in a broader sense, the United States economy.

do not. See Philip R. Stein, Kenneth Duvall, From RMBS to SLABS: Is History Repeating Itself?, NAT'L L. REv. (Apr. 3, 2019), https://www.natlawreview.com/article/rmbs-to-slabshistory-repeating-itself [https://perma.cc/4BEG-9FBY]; see also Mortgage-Backed Securities, FINRA, https://www.finra.org/investors/learn-to-invest/types-investments/bonds/ types-of-bonds/mortgage-backed-securities [https://perma.cc/2R82-5BLX].

15. See, e.g., Prachi Talathi \& Jinwen Chen, Moody's Downgrades Class 2010 A-1-7 Issued by New Mexico Educational Assistance Foundation, and Continues to Keep It on Review, Moody's (June 19, 2020), https://www.moodys.com/research/Moodys-downgrades-Class-2010-A-1-7-issued-by-New-PR_426902 [https://perma.cc/9M6W-TYW2] (discussing Moody's decision to downgrade a particular class of student loan bonds by one issuer due to expected loss to the tranche); Edward Bankole \& Andrew Lipton, Moody's Rates Academic Management Services Student Loan Securitization, Aaa, Moody's (Feb. 12, 2002), https://www.moodys.com/research/MOODYS-RATES-ACADEMIC-MANAGEMENT-SERVICES-STUDENT-LOAN-SECURITIZATION-Aaa-PR_52890

[https://perma.cc/M7TK-Q3RN] (rating over \$335 million of then newly issued SLABS as "Aaa," the agency's highest rating).

16. Most student loans are federally guaranteed; however, less than $10 \%$ of all student loan debt is held by private lenders, which is non-guaranteed. See Bankole \& Lipton, supra note 15 .

17. Many types of debts can be discharged in Chapter 7 and Chapter 13 bankruptcy proceedings, including mortgage debt. Ordinarily, liens, back-taxes, child support, and alimony cannot be discharged. See Discharge in Bankruptcy-Bankruptcy Basics, U.S. COURTs, https://www.uscourts.gov/services-forms/bankruptcy/bankruptcy-basics/dischargebankruptcy-bankruptcy-basics [https://perma.cc/EN5T-64F4]; see also What Debt Cannot Be Discharged When Filing for Bankruptcy?, Investopedia (May 20, 2020), https:// www.investopedia.com/ask/answers/102814/what-debt-cannot-be-discharged-when-filingbankruptcy.asp [https://perma.cc/KQ2M-69H8]. Student loans are very, very rarely, if ever, discharged through bankruptcy proceedings. See Jason Iuliano, An Empirical Assessment of Student Loan Discharges and the Undue Hardship Standard, 86 Am. BANKR. L.J. 495, 505 (2012) (noting that only $0.1 \%$ of debtors even challenge the nondischargeability of their student loans). But see Rafael I. Pardo, The Undue Hardship Thicket: On Access to Justice, Procedural Noncompliance, and Pollutive Litigation in Bankruptcy, 66 FlA. L. REv. 2101, 2124-35, 2129 n.176 (2014) (arguing that the Iuliano study undercounted student loan proceedings). In fact, to the extent that a borrower's student loans are discharged in extremely limited cases in bankruptcy proceedings, it could be the case that this discharge stems from settlement agreements between borrowers and creditors that do not require judicial determinations of the borrower's undue hardship. See Aaron N. Taylor \& Daniel J. Sheffner, Oh, What a Relief It (Sometimes) Is: An Analysis of Chapter 7 Bankruptcy Petitions to Discharge Student Loans, 27 Stan. L. \& Pol’y Rev. 295, 297 (2016). 
This Article addresses this possibility, especially in light of the fact that rising unemployment in the wake of the COVID-19 crisis is sure to increase the rate of default on student loans. Part II of this Article describes the present student loan crisis in terms of available statistics and common student loan repayment programs. In addition, Part II of this Article explores what options are available when borrowers are unable to repay their loans-fully or in part-including income-based repayment programs, forbearance, and default. Next, Part III chronicles the development and operation of bankruptcy law in the context of student loans. Further, Part III of this Article explains how the Brunner test has resulted in all but a total prohibition against the discharge of student loans in bankruptcy proceedings. Part IV focuses on student loan asset-backed securities: what they are, how they operate, and how they generate profit. Lastly, this final part will draw the connection between student loan discharge via bankruptcy and its potential impacts on the SLABS market and the economy at large. This Article concludes with observations about how the current crisis levels of student loan debt, when combined with rising unemployment and recent bankruptcy court decisions, could impact the stability of the SLABS market and the broader economy.

\section{STUDENT LOANS IN CONTEXT}

\section{A. Trillions of Reasons}

Even before the onset of the COVID-19 pandemic, the upward trajectory of consumer debt approached worrisome levels, growing markedly every quarter since late 2013 to over $\$ 14$ trillion. ${ }^{18}$ The proportion of this debt accounted for by student loans has also systematically increased every year since the early 2000s. In fact, the amount of outstanding student loans in the United States has doubled in the last decade and has tripled since $2006 .{ }^{19}$ Student loan debt is the second largest source of consumer debt-more than triple the fourth largest consumer debt category, credit card debt, and over $\$ 200$ billion more than the third largest consumer debt category, auto loans. ${ }^{20}$ Today, in the United States, 44.7 mil-

18. See, e.g., Mark DeCambre, U.S. Consumer Debt Is Now Above Levels Hit During the 2008 Financial Crisis, MarketWatch (June 25, 2019, 9:12 PM), https://www.mar ketwatch.com/story/us-consumer-debt-is-now-breaching-levels-last-reached-during-the2008-financial-crisis-2019-06-19 [https://perma.cc/Q5RS-35LR]; see also Friedman, supra note 11.

19. See, e.g., Lauren Theisen, Study: Barely Anyone is Paying Off Their Student Loans, and the Debt Keeps Rising, N.Y. DAILY News (Jan. 16, 2020), https:// www.nydailynews.com/news/national/ny-barely-anyone-is-paying-off-their-student-loans20200117-743fvux7ijae5jnrdyecoe6ypy-story.html [https://perma.cc/8754-4ED7].

20. See, e.g., Magdelena Szmigiera, Value of Debt Owned by Consumers in the United States as of September 2019, by Type, STATISTA (Dec. 19, 2019), https://www.statista.com/ statistics/500814/debt-owned-by-consumers-usa-by-type/ [https://perma.cc/554F-TB3S]; Zack Friedman, Wait, My Student Loans Went up After 5 Years?, Forbes (Feb. 10, 2020, 8:30 AM), https://www.forbes.com/sites/zackfriedman/2020/02/10/student-loans-balance-in crease/\#2096a1884625 [https://perma.cc/4HTR-KKMX]. 
lion borrowers owe approximately $\$ 1.6$ trillion in student loan debt. ${ }^{21}$

Student loans affect graduates of every type of higher education institution and at every level of higher education. In fact, only three out of every ten college graduates leave their undergraduate institutions without student loan debt. ${ }^{22}$ While $66 \%$ of public college graduates end up with student loan debt, $75 \%$ of non-profit college graduates carry student loan debt after graduation. ${ }^{23}$ And $88 \%$ of those who graduated from for-profit colleges incur student loan debt. ${ }^{24}$

This year, the average student loan debt per borrower is $\$ 32,731$ - costing borrowers on a standard repayment plan around $\$ 383$ per month, on average. ${ }^{25}$ But this average masks the fact that student loan debt amounts - and in turn, monthly payment amounts - vary wildly depending on a host of factors including repayment status, ${ }^{26}$ race, ${ }^{27}$ gender, ${ }^{28}$

21. See, e.g., Friedman, supra note 11 . We should note here that over $11 \%$ of all student debt is securitized, based on 2019 numbers. See Fixed Income Outstanding, SIFMA, https://www.sifma.org/resources/research/fixed-income-chart/ [https://perma.cc/P5MBTTF4] (listing the student loan ABS market at $\$ 158.9$ billion).

22. See, e.g., Friedman, supra note 11.

23. Id.; see Matthew P. Diehr, The Looming Threat Posed to Student Loan Lenders and Servicers by State-Level Actors in an Era of Federal Regulatory Remission, 65 FED. LAw. 42, 43 (2018). In fact, the average college graduate of the class of 2016 owed $70 \%$ more in student loan debt than the average member of the Class of 2006. Id. at 45.

24. Friedman, supra note 11; Adrej Bastrikin, Student Loan Debt Statistics, EducATIONDATA.ORG (Apr. 12, 2020), https://educationdata.org/student-loan-debt-statistics/ [https://perma.cc/P62J-FMME].

25. Friedman, supra note 11; Bastrikin, supra note 24.

26. See Stefan Lembo Stolba, Only Half of All Student Loans Are Currently in Repayment, EXPERIAN (Oct. 15, 2019), https://www.experian.com/blogs/ask-experian/research/ student-loan-debt-and-repayment/ [https://perma.cc/FJ8J-Y3CG ] (noting that only 55.8\% of outstanding student loans are in repayment, which means that monthly payment amounts for many borrowers is $\$ 0$ ).

27. See Robert Hiltonsmith, Demos Small loans, Big Risks: Major ConseQUENCES FOR STUDENT DebTORs 2, 6 (2017), https://www.demos.org/research/small-loansbig-risks-major-consequences-student-debtors [https://perma.cc/ZE86-UNWM] (noting that "[b]orrowers of color face greater difficulty repaying their loans"); Jason N. Houle \& Fenaba R. Addo, Racial Disparities in Student Debt and the Reproduction of the Fragile Black Middle Class, 5 Socio. Race \& Ethnicity 562 (2018) (focusing on how student loan debt affects black youth); Janice McCabe \& Brandon A. Jackson, Pathways to Financing College: Race and Class in Students' Narratives of Paying for School, 3 Soc. Currents 367, 367-68 (2016) (focusing primarily on differences between white and African-American students); Demos, Latinos, Student Debt, and Financial Security (2016), https:/ /www.demos.org/sites/default/files/publications/Latinos\%20Student\%20Debt $\% 20$ and \%20 Financial\%20Security.pdf [https://perma.cc/C5MY-WHBG] (focusing on the impact of student loans on Latinos).

28. See Kevin Miller, Am. Ass'n Univ. Women, Deeper in Debt: Women and STUdENT LOANS, 1, 36 (2017), https://files.eric.ed.gov/fulltext/ED580345.pdf [https:// perma.cc/9TVR-TT8C] (noting that two-thirds of all student loan debt is held by women); see also Valerie Fontenot, Disparities in Student Loans: How Did We Get Here and What Can We Do?, ABA J. (July 16, 2019), https://www.americanbar.org/groups/litigation/com mittees/diversity-inclusion/articles/2019/summer2019-disparities-in-student-loans/ [https:// perma.cc/33GP-RRZ3]. 
socioeconomic status, ${ }^{29}$ and education level. ${ }^{30}$ When looking at borrowing statistics, clear patterns emerge with respect to who is most likely to incur student loans to finance a postsecondary education, and equally as apparent is who is most likely to be able to meet their repayment obligations.

\section{B. Student Loan Repayment}

Even for borrowers enrolled in a repayment plan that results in loan forgiveness, when students borrow funds to help pay for their cost of attendance at a postsecondary institution, it is with the intention of being able to pay back most, if not all, of these funds once they obtain adequate post-graduate employment. Repayment is easier for some borrowers than it is for others and depends on whether borrowers graduate from their respective higher education institutions to begin with and whether they secure employment, as well as their post-graduate earnings and living expenses. Since 2010, most student loans have been issued under the Federal Direct Loan Program, meaning that when the loan enters repayment, the borrower pays back the federal government through an approved loan servicer. Once payments on a borrower's student loans become due, by default, student loans are entered into the Standard Repayment Plan. Under the default terms of this repayment plan, the borrower will be expected to pay back the same amount each month over ten years, or 120 monthly payments. ${ }^{31}$ The largest concentration of borrowers-about 12.5 million-are enrolled in the Standard Repayment Plan, which is often called the "level repayment plan" because the monthly repayment

29. See, e.g., Dirk Witteveen \& Paul Attewell, Social Dimensions of Student Debt: A Data Mining Analysis, 49 J. Student Fin. Aid 1, 16-17 (2019); Jason N. Houle, Disparities in Debt: Parents' Socioeconomic Resources and Young Adult Student Loan Debt, 87 Soc. EDuc. 53, 55 (2013) ("Children from middle-income families make too much money to qualify for student aid packages, but they do not have the financial means to cover the costs of college."); see also Hillary Hoffower, 6 Findings That Show the Dire State of America's Middle Class, Bus. Insider (May 23, 2019), https://www.businessinsider.com.au/ america-shrinking-middle-class-debt-homeownership-retirement-savings-2019-5 [https:// perma.cc/ZYY6-8S65] (noting that "nearly half" of middle-class students have student loans, compared to $39 \%$ of affluent students).

30. For example, aspiring lawyers borrow an average in excess of $\$ 115,000$ to pay for their formal legal educations. Law School Costs, L. Sch. Transparency, https:// data.lawschooltransparency.com/costs/debt/ [https://perma.cc/82L6-V78U]. For further discussion of the impact of student loans on the careers of law school graduates, see Christopher J. Ryan, Jr., Paying for Law School: Law Student Loan Indebtedness and Career Choices, 2021 U. ILl. L. Rev. (forthcoming 2021). Likewise, in 2017, the average medical school graduate took on over $\$ 190,000$ in student loan debt-costs which only continue to increase with rising tuition rates. See, e.g., Kevin Payne, Average Medical School Debt: How Much It Really Costs to Be a Doctor, Student Loan Planner (Feb. 7, 2020), https:// www.studentloanplanner.com/average-medical-school-debt/ [https://perma.cc/GBD834YL].

31. See, e.g., Friedman, supra note 11; see also Ryan Lane, What Is the Standard Repayment Plan on Student Loans?, NerdWallet (Mar. 25, 2019), https:// www.nerdwallet.com/blog/loans/student-loans/standard-repayment-plan-student-loans/ [https://perma.cc/X2CL-JLNG]; Max Fay, Income-Based Repayment of Student Loans, DeBT.ORG, https://www.debt.org/students/income-based-repayment-loans/ [https:// perma.cc/2W3D-TZVB]. 
amounts do not change over time. ${ }^{32}$ This repayment structure is most advantageous for student borrowers who graduate and immediately secure employment that compensates them with enough income to cover their student loan debt obligations on top of their cost of living. ${ }^{33}$ This plan also allows borrowers a way to avoid paying an exorbitant amount of interest; however, when graduates are underemployed-or otherwise do not receive adequate compensation enabling them to repay their loansthere are alternative repayment plans into which the borrower may enter. These plans include Graduated Repayment, Income-Contingent Repayment, Income-Based Repayment, Pay As You Earn, and Revised Pay As You Earn, which are described in detail below. ${ }^{34}$

Even though the majority of people remain in the Standard Repayment Plan by default, there are seven additional repayment plans that can be elected by borrowers. ${ }^{35}$ The most popular alternative repayment plans are Revised Pay As You Earn (REPAYE) and Income-Based Repayment (IBR), in which 2.8 million and 2.9 million borrowers are enrolled, respectively. ${ }^{36}$ Using these plans, borrowers can significantly lower their monthly payments. ${ }^{37}$ These plans calculate a borrower's monthly payments based on a certain percentage of a borrower's "discretionary" monthly income. ${ }^{38}$ Discretionary income, for the purpose of these programs, is the difference between a borrower's annual income and 150\% of the poverty guideline for that borrower's respective state and family size. ${ }^{39}$ Under either of these plans, if a borrower earns less than $150 \%$ of the poverty level for their respective family size, the borrower is not required to pay anything on her loan for as long as their financial situation persists. ${ }^{40}$

IBR was created in 2009 and is available to federal student loan borrowers with either direct loans or loans through the Federal Family Education Loan Program (FFELP). ${ }^{41}$ Depending on whether or not the borrower is a new borrower as of July 1, 2014, the expected IBR monthly payment is calculated to be between $10 \%$ and $15 \%$ of the borrower's

32. Friedman, supra note 11.

33. See, e.g., Camilo Maldonado, A Guide to Federal Student Loan Repayment Plans, Forbes (Feb. 25, 2020, 1:37 PM), https://www.forbes.com/advisor/loans/a-guide-to-federalstudent-loan-repayment-plans/ [https://perma.cc/F9LL-FZ88].

34. See id.

35. See id.; see also Repayment Plans: Choose the Federal Student Loan Repayment Plan That's Best for You, FeD. STUdENT AID, https://studentaid.gov/manage-loans/repay ment/plans [https://perma.cc/SV8X-XA3Y].

36. See, e.g., Friedman, supra note 11.

37. Maldonado, supra note 33.

38. See, e.g., id.

39. Id.

40. What Are These Programs?, IBRINFO, http://www.ibrinfo.org/what.vp.html [https:// perma.cc/QA5Y-94S7].

41. See College Cost Reduction and Access Act, Pub. L. No. 110-84, § 203, 121 Stat. 784, 792-95 (2007) (codified as amended at 20 U.S.C. $\$ 1098$ e) (setting forth the requirements for the IBR program); see also Income-Driven Repayment Plans, Fed. STUdent AID, https://studentaid.gov/manage-loans/repayment/plans/income-driven [https:// perma.cc/ZD9V-H29G]; What Are These Programs?, supra note 40. 
monthly discretionary income. ${ }^{42}$ IBR has a safeguard that ensures that a borrower's monthly payment will never be more than what they would pay under the Standard Repayment Plan. ${ }^{43}$ Under this plan, borrowers must recertify their income annually and the required monthly payment amount will continuously recalculate based on the borrower's current income. ${ }^{44}$ After twenty-five years of qualifying payments, loans under an IBR plan are eligible for discharge via forgiveness. ${ }^{45}$ Although forgiveness is a helpful remedy, there are obvious negative externalities that surface in relation to the program's tax ramifications. ${ }^{46}$

In many respects, the REPAYE program operates along the same lines as the IBR program. Under REPAYE, a borrower's discretionary income calculation is derived in the same way that IBR calculates discretionary income, and a borrower's monthly payment is capped at $10 \%$ of the borrower's discretionary monthly income. ${ }^{47}$ However, under REPAYE, the repayment period depends on whether or not the borrower has student loans from undergraduate or graduate studies. ${ }^{48}$ If the borrower has exclusively undergraduate loans, the repayment period is twenty years. ${ }^{49}$ If any of the loans originated from the borrower's graduate studies, the repayment period increases to a total of twenty-five years. ${ }^{50}$ But REPAYE is distinct from IBR in another key respect: there is no cap on monthly payment amounts. ${ }^{51}$ This means that if a borrower's income increases substantially, the borrower's monthly payments under a REPAYE plan could potentially exceed what their monthly payments would be under the default Standard Repayment Plan. ${ }^{52}$

That said, REPAYE and IBR remain wildly popular repayment options, especially for borrowers who have low-to-moderate incomes and large amounts of student loan debt. ${ }^{53}$ However, both IBR and REPAYE plans have considerable downsides that may be overlooked by many borrowers who enroll in these repayment plans early in their loan repayment periods because the severity of the following negative effects are not seen until much later in their repayment period. The adverse effects associated with these programs can impact a borrower's ability to repay the bor-

42. See, e.g., Maldonado, supra note 33.

43. Id.

44. See Repayment Plans, supra note 35; see also What Are These Programs?, supra note 40 .

45. What Are These Programs?, supra note 40.

46. See infra Section I.C.1.

47. See, e.g., Rebecca Lake, REPAYE Could Lower Your Student Loan PaymentsHere's How, Fox Bus. (Apr. 10, 2020), https://www.foxbusiness.com/money/repaye-lowerstudent-loan-payments [https://perma.cc/SXM5-VUR7]; see also Maldonado, supra note 33.

48. See Maldonado, supra note 33.

49. Id.

50. Id.

51. See, e.g., Elyssa Kirkham, What Is the REPAYE Plan and How Does It Work?, BALANCE (July 27, 2020), https://www.thebalance.com/revised-pay-as-you-earn-repaye4776588 [https://perma.cc/KU7S-RK9A].

52. Id.

53. See, e.g., Maldonado, supra note 33. 
rower's student loans in full, and when these effects arise for many borrowers on a large scale, it could test the limits of the federal guarantee on many of these loans. As such, these effects are further explored in the sections below.

\section{Never-Ending Interest}

One of the most severe consequences of the IBR and REPAYE plans is substantial interest that accrues on the borrower's loans even before the loans enter the repayment period. ${ }^{54}$ Many borrowers who enrolled in IBR, REPAYE, or similar types of plans, did so in order to make repaying their student loan debt more manageable. ${ }^{55}$ Although these plans can offer short-term relief, these loans can potentially become much more expensive in the long run because the interest on the loans compounds when the borrower's monthly payments do little to repay the principal balance of the loan amount. ${ }^{56}$ Borrowers enrolled in these programs have become discouraged and overwhelmed by the fact that their payments never seem to make a dent in their loan balances. ${ }^{57}$ In fact, in many cases, borrowers enrolled in these repayment plans have seen their total loan balances increase despite their making the required monthly payments. ${ }^{58}$

Although student loan originations have decreased, aggregate balances continue to grow rapidly because borrowers are, in general, taking longer to repay their existing loans by utilizing repayment plans like IBR and REPAYE. ${ }^{59}$ In fact, a recent study by Moody's Investors Service showed that almost half of the borrowers who took out loans between 2010 and 2012 have made no progress at all on paying down the principal balance on their student loans. ${ }^{60}$ This reality quite significantly impacts the SLABS market; to the extent that borrowers do not pay off their loans in time- the outstanding loan amounts of which now total billions of dollars-issuers of SLABS must extend maturity dates to avoid ratings downgrades. ${ }^{61}$

54. See, e.g., Friedman, supra note 20.

55. See, e.g., id.

56. See, e.g., id.

57. Id.

58. Id.

59. See, e.g., Theisen, supra note 19.

60. See, e.g., Jeff Cox, Student Debt Is Over \$1.6 Trillion and Hardly Anyone Is Paying Down Their Loans, CNBC (Jan. 16, 2020, 6:27 PM), https://www.cnbc.com/2020/01/16/stu dent-loan-debt-is-over-1point6-trillion-and-balances-arent-going-down.html [https:// perma.cc/EQD9-GGHS] (discussing how borrowers who took out loans between 2010 and 2012 felt strong effects of the Great Recession which lead to their inability to pay down their loans and how only $51 \%$ of individuals who borrowed during this time have been able to make any progress in paying down their debts).

61. See Cezary Podkul, A Borrower Will Be 114 When Bonds Backed by Her Student Loans Mature, WALl ST. J. (Jan. 7, 2020, 5:30 AM), https://www.wsj.com/articles/a-borrow er-will-be-114-when-bonds-backed-by-her-student-loans-mature-11578393002 [https:// perma.cc/ZEZ9-RLPT] (describing the practices of SLABS issuers to extend maturity dates in an effort to avoid downgrading by the credit rating agencies of the investment vehicles they issued). 
Also, as mentioned above, after making payments for the designated period of time, borrowers are eligible to receive student loan forgiveness on the remaining balance of their student loans. ${ }^{62}$ As the old adage goes, "if it seems too good to be true, it most likely is." Borrowers must make twenty-five years of on-time payments to be eligible for forgiveness. ${ }^{63} \mathrm{Be}$ yond even that, student loan forgiveness-which seems to be purely a boon-is not without its consequences.

\section{Student Loan Forgiveness and the "Tax Bomb"}

Assume a borrower wanted to lower her monthly payments and thus decided to enroll in one of the aforementioned alternative repayment plans. Over twenty-five years, this borrower consistently made on-time, qualifying payments toward her student loan balance. After making these 300 monthly payments, the borrower's loan still has a balance of $\$ 90,000$; this balance is then forgiven. However, the borrower does not get off "scot-free," as one may assume when the word "forgiveness" is used to describe debt relief. Instead, when the borrower's student loan balance is forgiven, all $\$ 90,000$ of it becomes taxable as income to the borrower. ${ }^{64}$

By way of an illustration, assume the borrower with a $\$ 90,000$ remaining student loan balance is a single person with an income $\$ 40,000$ per year. Based on the borrower's salary alone, the borrower would be placed into the second lowest tax bracket. ${ }^{65}$ The second lowest tax bracket applies to single individuals making between $\$ 9,876$ and $\$ 40,125$ per year. ${ }^{66}$ The IRS imposes a $12 \%$ tax rate on the income of taxpayers who fall into this bracket. ${ }^{67}$ This means that, under normal circumstances, the borrower would be required to pay $\$ 4,602.50$ in federal income tax in 2020 .

62. Note that the period for repayment is typically between twenty and twenty-five years. See, e.g., Friedman, supra note 20.

63. Id.

64. See, e.g., Ryan Lane, Should You Worry About a 'Student Loan Forgiveness Tax Bomb'?, NASDAQ (Jan. 16, 2020, 6:27 PM), https://www.nasdaq.com/articles/should-youworry-about-a-student-loan-forgiveness-tax-bomb-2020-01-16 [https://perma.cc/K9PUGP7V]. However, we should note that there is an exception to the "tax bomb": where a debtor is insolvent at the time that a debt is forgiven, the debt forgiveness is not considered ordinary income and thus, is not taxable. See I.R.C. § 108(a)(1)(B). While student loan forgiveness has generated fairly widespread support, not everyone agrees on whether it should exist or how it should be implemented. See, e.g., Zack Friedman, Should You Really Get Student Loan Forgiveness?, Forbes (Jan. 28, 2020, 8:30 AM), https://www.forbes.com/ sites/zackfriedman/2020/01/28/is-student-loan-forgiveness-fair/\#303826582017 [https:// perma.cc/XJK4-BM6A] (discussing the arguments for and against student loan forgiveness); see also Large Scale Debt Forgiveness May Benefit High Income Borrowers: Higher Ed Associations, Diverse Educ. (Apr. 20, 2020), https://diverseeducation.com/article/ 174180/ [https://perma.cc/E6TF-36XW] (reporting on a congressional letter, written by American Council on Education and thirty-one other higher education institutions, cautioning Congress that large scale debt forgiveness could benefit high income borrowers, who-in their view-do not require such assistance).

65. These calculations are based on the 2020 Federal Income Tax Brackets. See, e.g., I.R.C. § 1(j); Rev. Proc. 2019-44, 2019-47 I.R.B. 1093 (noting the inflation adjustment to I.R.C. $\S 1(\mathrm{j})$ for 2020 for unmarried individuals and single taxpayers at Table 3 ).

66. See I.R.C. § 1(j); Rev. Proc. 2019-44, 2019-47 I.R.B. 1093.

67. See id. 
However, taking the "tax bomb" that loan forgiveness carries into consideration, the borrower's total income would equal $\$ 130,000$. This would cause the borrower to jump up two tax brackets and end up in the $\$ 82,526$ to $\$ 163,300$ tax bracket. ${ }^{68}$ The appropriate tax rate for this new bracket is $24 \%$, or double the tax rate from the borrower's previous tax bracket. ${ }^{69}$ This means that the year the borrower's loans are forgiven, the borrower would owe $\$ 25,279.50$ in income tax. In other words, the borrower would owe more than $63 \%$ of her annual salary in income tax, due 120 days from receipt. In a nutshell, this is the tax bomb, incident to student loan forgiveness, that the borrower must now pay to the IRS. If the borrower is unable to pay the borrower's full tax balance up front, the borrower can elect to set up an installment plan with the IRS or seek a short-term extension. However, the borrower will be subject to a monthly penalty equal to at least $0.25 \%$ of the unpaid balance. ${ }^{70}$

It is important to note that not all alternative repayment plans are subject to the tax bomb, but the most popular ones-IBR and REPAYEare subject to this consequence. ${ }^{71}$ Unfortunately, many borrowers are unaware of this substantial consequence until it is too late. Likewise, SLABS holders may not be aware of the consequences of forgiveness either. Given that the federal government backs the debt balance of FFELP loans, which represent an entire class of SLABS, these SLABS holders might not expect to incur losses if forgiveness rates remain level. Nor would SLABS holders have a reason to suspect federal loan forgiveness on individual loans could alter the return on a SLABS investment because investors are functionally protected from noticing the impact of forgiveness: the government forgives the borrower and pays the loan servicer, and in turn, pays the SLABS holder. However, there is a very real possibility that-even if forgiveness rates remain level-a spike in borrowers entering forbearance or deferment, being forgiven of their loans, or defaulting on them could result in SLABS issuers "fail[ing] to repay investors[,] . . . something that has never happened before" but may well be on the horizon. ${ }^{72}$

68. Id.

69. Id.

70. See, e.g., What Happens If You Owe Taxes?, H\&R BLock, https:// www.hrblock.com/tax-center/irs/audits-and-tax-notices/owe-the-irs-back-taxes/ [https:// perma.cc/D4BY-UH9K].

71. See, e.g., Lane, supra note 64.

72. See, e.g., Joy Wiltermuth, The Recovery Is Happening, Right? Why \$9 Billion of Student Loan Bonds Just Got Downgraded, MarketWatch (June 8, 2020, 12:20 PM), https://www.marketwatch.com/story/the-recovery-is-happening-right-why-9-billion-of-student-loan-bonds-just-got-downgraded-2020-06-05 [https://perma.cc/9TX9-ZHRJ] (discussing Moody's recent decision to downgrade " $\$ 9$ billion worth of bonds made up entirely of government-backed student loans and t[ake] negative actions on another $\$ 2$ billion, due to the 'contraction in economic activity and an increase in unemployment due to the coronavirus outbreak" " because the rating agency "thinks the [Federal Family Education Loans Program (FFELP)] bonds could fail to repay investors at maturity, something that has never happened before, and could spark a wave of bond defaults"); see also Podkul, supra note 61 . 


\section{Inability to Meet Repayment Obligations}

When borrowers cannot meet their repayment obligations, there are three principal courses of action by which they can seek relief. These courses of action include placing their loans in forbearance, entering deferment, or, ultimately, defaulting on their loans through non-payment. Because almost no student loan borrowers seek to discharge their student loans in bankruptcy, given the unlikelihood of doing so successfully, the first two options-placing student loans in forbearance or defermentare the de facto options that borrowers face in the near-term and are theoretically more optimal than the last option for most borrowers. ${ }^{73}$

\section{Forbearance and Deferment: Short-Term Solutions}

As of the third quarter of 2019, 2.8 million borrowers tied up their loans in forbearance, a process that freezes repayment obligations but does nothing to stop interest from accruing on student loans. ${ }^{74}$ The total owed by those borrowers is equal to approximately $\$ 122.9$ billion. ${ }^{75}$ There are two different types of forbearance that apply in the context of federal student loans: general and mandatory. ${ }^{76}$ General forbearance, also known as discretionary forbearance, is obtained when a borrower's application is accepted..$^{77}$ Mandatory forbearance is applied in limited circumstances, including when the borrower's payment is more than $20 \%$ of her gross monthly income or when the borrower is a National Guard member who is activated. ${ }^{78}$ Forbearance allows borrowers to temporarily delay their loans. ${ }^{79}$ During this time, the loans continue to accrue interest, which capitalizes once loans switch out of forbearance and back into a repayment plan..$^{80}$ The number of borrowers with loans in forbearance has risen significantly in light of the relief that the CARES Act provides for borrowers during the COVID-19 crisis, but data is not yet available on how many borrowers have placed their loans in forbearance during this time. ${ }^{81}$

73. See Iuliano, supra note 17; Jason Iuliano, Student Loans and Surmountable Accessto-Justice Barriers, 68 FlA. L. REv. 377, 378, 380, 389 (2016) (emphasizing-in a more recent study by the same author-that many student loan borrowers do not pursue discharge in bankruptcy because they may not know about it as a potential option, they risk opposition in court to do so, and they could wait for years in appeals of court decisions before being granted relief).

74. See, e.g., Friedman, supra note 11.

75. Id.

76. See, e.g., Katie Brazis, What Is Student Loan Forbearance and Should You Consider It?, Coll. INv'R (Mar. 20, 2020), https://thecollegeinvestor.com/20236/student-loanforbearance/ [https://perma.cc/5CWF-6UYD].

77. Id. (noting that general forbearance may be applied for in the event that the borrower is unable to make payments due to medical expenses, financial difficulties, employment change, etc.).

78. $I d$.

79. $I d$.

80. Id.

81. Coronavirus and Forbearance Info for Students, Borrowers, and Parents, Fed. STU DENT AID, https://studentaid.gov/announcements-events/coronavirus [https://perma.cc/ 6RWV-795W]. That said, researchers have uncovered data from private and FFELP 
On the other hand, before COVID-19, 3.6 million borrowers nationwide had over $\$ 128$ billion in student loans in deferment. ${ }^{82}$ Deferment allows borrowers to delay their loans without interest. ${ }^{83}$ There are different types of deferment, including, but not limited to, education, active military duty, unemployment, and cancer treatment. ${ }^{84}$ It is important to note that there is a distinction between deferment on federal student loans and deferment on private loans. ${ }^{85}$ When a private lender offers deferment, they are actually offering forbearance because the loan still accrues interest during the time the borrower's loan is in deferment. ${ }^{86}$ Essentially, there is no such thing as a true "deferment" in the context of private student loans; this matters for the SLABS sector, given that private loans can be securitized and offered to SLABS investors. However, the vast majority of borrowers in deferment are utilizing the classification's full protection from interest accrual on their federal student loans, which is unavailable to private student loan borrowers.

\section{Default: The "End of the Road"}

When a borrower is unable to pay back her student loans, default is the borrower's last stop-short of bankruptcy. As of 2019, 5.5 million Americans have defaulted on over $\$ 119.8$ billion in student loan debt. ${ }^{87}$ According to the Federal Reserve, $10.8 \%$ of all student loans are either delinquent or in default. Approximately $3.1 \%$ of student loans are considered delinquent, and the remaining $7.7 \%$ are in default. 88

Delinquency and default are generally grouped together because the latter is a consequence of the former. An account is considered "delinquent" as soon as a borrower misses a payment on the borrower's student loans. ${ }^{89}$ It is easy for a borrower to miss a payment, but it is often the case that the borrower can rectify the issue and catch up on payments. Default occurs when an account is delinquent for an extended period of time, usually starting when the borrower has been delinquent on payments for

loans-which back SLABS issues-that have entered forbearance in the last five months. Ben Kaufman, Amid the Coronavirus, Struggling Private Student Loan Borrowers Pause Payments Without a Path to Get on Track, Student Borrower Prot. Ctr. (June 8, 2020), https://protectborrowers.org/slabs/ [https://perma.cc/8TYU-XTPE ] (illustrating the dramatic increases in borrowers whose loans back SLABS entering forbearance and default since January 2020).

82. See, e.g., Friedman, supra note 11.

83. See, e.g., Robert Farrington, The Complete and Easy Guide to Student Loan Deferment, Coll. INV'R (June 8, 2020), https://thecollegeinvestor.com/9949/the-complete-guideto-student-loan-deferments/ [https://perma.cc/6SFV-ZMKG].

84. See, e.g., Ryan Lane, Deferment vs. Forbearance: Which Is Right for Your Student Loans?, NeRDWALlet (July 14, 2020), https://www.nerdwallet.com/blog/loans/studentloans/student-loan-deferment-forbearance/ [https://perma.cc/SFL7-5GDR].

85. See, e.g., Brazis, supra note 76.

86. Id.

87. See, e.g., Friedman, supra note 11.

88. Id.

89. See, e.g., Kali Hawlk, What's the Difference Between Student Loan Delinquency and Default?, Student Loan Hero (Aug. 8, 2019), https://studentloanhero.com/featured/ difference-between-student-loan-default-delinquency/ [https://perma.cc/EPT6-NXG6]. 
270 days. And default is no small problem. In 2017 alone, well before the onset of COVID-19, over one million borrowers defaulted on nearly $\$ 20$ billion worth of student loan debt. ${ }^{90}$

It is important to acknowledge that default does not affect all student loan borrowers equally. Approximately $60 \%$ of all students need to borrow student loans to attend a four-year public college. ${ }^{91}$ When looking at the student loan debt burdens on individual races, however, the differences become stark. Though $59.9 \%$ of White students need to borrow student loans to attend a university, a staggering $86.8 \%$ of Black students need to do the same. ${ }^{92}$ Likewise, default differentially affects borrowers based on race. While only $4 \%$ of White borrowers default on their student loans, Latino borrowers are over two times (8.6\%) more likely to default than their White peers. ${ }^{93}$ Even more severely, $20.6 \%$ of Black borrowers default on their student loans-over five times the rate at which White borrowers default. 94

These glaring differences illustrate how paying for higher education is inherently unequal and demands greater scholarly attention than can be given within the scope of this Article. However, it is worthwhile to consider one potential explanation as to why Latino and Black borrowers default at higher rates than their White counterparts: Latino and Black borrowers tend to incur substantially more student loan debt when compared to other racial or ethnic groups. ${ }^{95}$ The descriptive fact that Black and Latino borrowers carry greater student loan debt loads augments the

90. See Ben Miller, Who Are Student Loan Defaulters?, Ctr. for Am. Progress (Dec. 14, 2017), https://www.americanprogress.org/issues/education-postsecondary/reports/ 2017/12/14/444011/student-loan-defaulters/ [https://perma.cc/YUW4-59K8] (citing Default Rates, Fed. STUdent Aid, https://studentaid.ed.gov/sa/about/data-center/student/default [https://perma.cc/984T-W2P8]); see also Matthew Bruckner, Brook Gotberg, Dalié Jimeénez \& Chrystin Ondersma, A No-Contest Discharge for Uncollectible Student Loans, 91 U. Colo. L. Rev. 183, 189 n.25 (2020) ("This [estimate] understates the magnitude of the problem, as student loans are only in default after 270-360 days of non-payment, suggesting that many more borrowers are seriously behind on their payments, although not yet in default. Further this figure does not include loans in forbearance. Even with these depressed figures, the student loan default rate is higher than the default rate for auto loans, of which only 8.5 percent are at least thirty days delinquent.").

91. See, e.g., Rebecca Safier, Study: Student Loans Weigh the Heaviest on Black and Hispanic Students, Student Loan Hero (Sept. 17, 2018), https://studentloanhero.com/ featured/study-student-loans-weigh-heaviest-black-hispanic/ [https://perma.cc/J74ZVZBB].

92. Id.

93. Note that $8.6 \%$ of Latino borrowers default on their student loans. See e.g., Chris Arnold, Student Loans a Lot Like the Subprime Mortgage Debacle, Watchdog Says, NPR (Dec. 9, 2019, 4:37 PM), https://www.npr.org/2019/12/09/785527874/student-loans-a-lot-likethe-subprime-mortgage-debacle-watchdog-says [https://perma.cc/JD6T-8JJW].

94. Id.

95. See, e.g., Richard Pallardy, Racial Disparities in Student Loan Debt, SAVING For Coll. (Aug. 27, 2019), https://www.savingforcollege.com/article/racial-disparities-in-stu dent-loan-debt [https://perma.cc/L785-EXDS]; see also Safier, supra note 91; Michal Grinstein-Weiss, Dana C. Perantie, Samuel H. Taylor, Shenyang Guo \& Ramesh Raghavan, Racial Disparities in Education Debt Burden Among Low- and Moderate-Income Households, 65 Child. \& Youth Servs. Rev. 166, 166 (2016); Judith Scott-Clayton \& Jing Li, Black-White Disparity in Student Loan Debt More Than Triples After Graduation, BrooKINGS (Oct. 20, 2016), https://www.brookings.edu/research/black-white-disparity-in-student- 
likelihood of default for these borrowers, narrowing their options when they are unable to make monthly payments on their loans. Ultimately, in default, borrowers are faced with two options, broadly speaking: to repay-either by paying their debt in full or by rehabilitating their loans by entering into a repayment plan-or to stop repaying their loans. Typically, this is not much of a choice at all, and those who are in default must seek other remedies for their problem.

\section{SQUARING STUDENT LOANS WITH BANKRUPTCY PRINCIPLES}

\section{A. How Bankruptcy Law Operates in the Context of STUdent LoAns}

In the 120 years since the passage of the Bankruptcy Act of 1898, consumer bankruptcy in the United States has occupied a relatively borrower-friendly position, offering borrowers a discharge of their debts in exchange for the surrender of non-exempt assets. ${ }^{96}$ However, the prospect of a creditor reaching a borrower's non-exempt assets is dubious because non-exempt assets are non-existent in the vast majority of consumer bankruptcy cases. Thus, most borrowers give up little to nothing to be released from their debt obligations under Chapter 7 of the U.S. Bankruptcy Code and may reap the benefit of "their future earnings free from the claims of [former] creditors." 97 The pro-borrower posture taken in bankruptcy proceedings under Chapter 7 of the U.S. Bankruptcy Code is tailormade for borrowers in times like these. ${ }^{98}$ When a crisis occurs, or all else fails and a borrower is unable to meet the borrower's debt repayment obligations, the borrower may consider filing for bankruptcy to relieve the borrower's debt obligation by going through a Chapter 7 bankruptcy proceeding. ${ }^{99}$

Overall, bankruptcy proceedings under Chapter 7 are most common for individuals; Chapters 11, 12, and 13 of the U.S. Bankruptcy Code are generally reserved for different circumstances, including organizational

loan-debt-more-than-triples-after-graduation/ [https://perma.cc/LCF6-LNZA]; Houle, supra note 29, at 60 .

96. See, e.g., Jean Braucher, Options in Consumer Bankruptcy: An American Perspective, 37 Osgoode Hall L.J. 155 (1999); see also Charles Jordan Tabb, The Historical Evolution of the Bankruptcy Discharge, 65 Aм. BANKR. L.J. 325 (1991).

97. Charles Jordan Tabb, The Death of Consumer Bankruptcy in the United States, in International Perspectives on Consumers' Access to Justice 264, 267 (Charles E.F. Rickett \& Thomas G.W. Telfer eds., 2003).

98. See Edward R. Morrison \& Andrea C. Saavedra, Bankruptcy's Role in the COVID-19 Crisis 3-4 (Columbia L. \& Econ. Working Paper, No. 624, 2020), https://papers.ssrn.com/sol3/papers.cfm?abstract_id=3567127\&dgcid=EJournal_htmlemail_law:economics:ejournal_abstractlink [https://perma.cc/D9JS-5M44] (focusing on Chapter 11 proceedings, but noting that bankruptcy law-including Chapter 7 - could mitigate the financial fallout from COVID-19).

99. See 11 U.S.C. $\$ \$ 727,1141,1228(\mathrm{a}), 1328(\mathrm{~b})$ (providing for discharge of debts under Chapters 7, 11, 12, and 13 of the Bankruptcy Code, respectively). 
bankruptcy filings. ${ }^{100}$ As alluded to above, during a Chapter 7 proceeding, the court liquidates all of the debtor's non-exempt assets and property and uses the proceeds of this liquidation to pay creditors. ${ }^{101}$ Once those funds have been depleted, the remaining unpaid debts-including mortgages and credit card debt-are then discharged by the bankruptcy court. ${ }^{102}$ However, there are certain exceptions in which the court will not grant the debtor a discharge in a Chapter 7 proceeding. ${ }^{103}$ These exceptions include a borrower's obligations to pay child support, debt arising from the debtor's willful and malicious infliction of injury, or fraudulently incurred debt. ${ }^{104}$ Likewise, student loan debt will not be discharged by a bankruptcy court unless the borrower can show that repayment of the student loan debt obligation would impose an "undue hardship" on the borrower. ${ }^{105}$ At first blush, the "undue hardship" bar would seem to be a fairly easy bar for a borrower to surmount, clearing a path to student loan discharge via bankruptcy. However, in practice, the task of meeting this standard is anything but easy, making student loan discharge through bankruptcy proceedings practically unavailable to borrowers.

\section{When Does an "Undue Hardship" Exist?}

The requirements for individuals seeking to discharge student loan debt via bankruptcy are mostly the same as those filing to discharge other types of debt; however, there are a few notable deviations. First, in addition to filing for bankruptcy, borrowers seeking to discharge student loans in bankruptcy proceedings may also be required to file an adversary proceeding. ${ }^{106}$ An adversary proceeding is necessary when there is a fundamental disagreement between a borrower and the borrower's creditor-typically having to do with the dischargeability of a debt. ${ }^{107}$ The adversary proceeding in bankruptcy court is essentially the equivalent of

100. The American Bankruptcy Institute reports that there was a total of 757,497 bankruptcy filings in 2019 and that nearly $62 \%$ - or 467,728 - of these were Chapter 7 filings. Newsroom: Statistics from Epiq, December 2019 Bankruptcy Statistics-State and District, AM. BANKR. INST., https://www.abi.org/newsroom/bankruptcy-statistics [https://perma.cc/ SH4N-HF8M]. It should be noted that these statistics do not indicate whether the Chapter 7 cases were converted from cases arising in another chapter of the Bankruptcy Code.

101. See 11 U.S.C. $\$ 704(a)(1)$ (requiring that a Chapter 7 trustee shall "collect and reduce to money the property of the estate for which such trustee serves").

102. Id. We note, here, that the bankruptcy court discharges the in personam liability of the borrower and not the in rem liability of the borrower in the example of mortgage debt discharged by the bankruptcy court.

103. See 11 U.S.C. $\$ 523(\mathrm{a})$.

104. Id. $\$ \S 523(\mathrm{a})(4)-(6)$.

105. See id. §523(a)(8).

106. For an example of how an adversary proceeding is filed, see FAQs: What Is an Adversary Proceeding and How Do I File a Complaint?, U.S. BANKr. CT. FOR Dist. OR., https://www.orb.uscourts.gov/faq/what-adversary-proceeding-and-how-do-i-file-complaint [https://perma.cc/AVE7-ZZ4B]. But see Douglas G. Baird \& Edward R. Morrison, Adversary Proceedings in Bankruptcy: A Sideshow, 79 Am. BANKR. L.J. 951, 951 (2005) (arguing that adversary proceedings are "a small (even trivial) part of the bankruptcy process").

107. FAQs, supra note 106. 
a civil complaint. ${ }^{108}$ This requires a borrower to file a written complaint outlining the circumstances of the borrower's case. ${ }^{109}$ Second, to successfully discharge student loans via bankruptcy, the borrower must allege and be able to demonstrate that the student loan debt would impose an undue hardship on the borrower and the borrower's dependents. ${ }^{110}$ In discussing the undue hardship standard, the U.S. Bankruptcy Code provides:

(a) A discharge under section $727 \ldots$ of this title does not discharge an individual debtor from any debt-

(8) unless excepting such debt from discharge under this paragraph would impose an undue hardship on the debtor and the debtor's dependents, for-

(A)(i) an educational benefit overpayment or loan made, insured, or guaranteed by a governmental unit, or made under any program funded in whole or in part by a governmental unit or nonprofit institution; or

(ii) an obligation to repay funds received as an educational benefit, scholarship, or stipend; or

(B) any other educational loan that is a qualified education loan, as defined in section 221(d)(1) of the Internal Revenue Code of 1986, incurred by a debtor who is an individual. ${ }^{111}$

While the U.S. Bankruptcy Code does not define a clear test-in the section of the code making student loans presumptively nondischargeableto determine whether an undue hardship exists, ${ }^{112}$ a majority of federal bankruptcy courts have adopted the Brunner test to determine whether or not such a hardship exists. ${ }^{113}$ Therefore, to succeed in discharging stu-

108. Id.

109. Id.

110. See, e.g., Rafael I. Pardo \& Michelle R. Lacey, The Real Student-Loan Scandal: Undue Hardship Discharge Litigation, 83 Am. Bankr. L.J. 179, 210 (2009).

111. 11 U.S.C. \$ 523(a)(8).

112. However, Congress does define "undue hardship" in another section of the code: 11 U.S.C. $\$ 524(\mathrm{~m})(1)$. See Bruckner, et al., supra note 90, at $194 \mathrm{n} .48$ (discussing this section and noting that it deals with "reaffirmation of debts which states that it shall be presumed that such agreement is an undue hardship on the debtor if the debtor's monthly income less the debtor's monthly expenses ... is less than the scheduled payments on the reaffirmed debt'" (alteration in original)). By and large, bankruptcy courts have not read $\S 523(\mathrm{a})(8)$ and $\S 524(\mathrm{~m})$ together, adding to the confusion around the "undue hardship" standard. See id.; Rafael I. Pardo \& Michelle R. Lacey, Undue Hardship in the Bankruptcy Courts: An Empirical Assessment of the Discharge of Educational Debt, 74 U. Cin. L. Rev. 405, 510-14 (2005).

113. The Brunner test is dominant test and is the correct test to apply in all circuit courts, aside from the Eighth and First Circuits, which use the "totality of the circumstances" test instead. See In re Frushour, 433 F.3d 393, 400 (4th Cir. 2005) ("An overwhelming majority of circuits has now adopted the Second Circuit's three-part Brunner test."); see also Bruckner, et al., supra note 90, at 195 n.49-50 ("Bankruptcy courts have generally been forced to use the Brunner test because the test has been widely adopted by the courts of appeals, thereby making it binding precedent that must be followed by bankruptcy courts in the adopting circuits."); Pardo \& Lacey, supra note 112, at 488 n.348 (discussing the origin of the totality of the circumstances test); Steven Frederick Werth, Student Loan Debt Dischargeability - Courts Discuss Limits of Brunner Test, Bloomberg L. (Jan. 27, 2016, 8:18 PM), https://news.bloomberglaw.com/bankruptcy-law/student-loan- 
dent loans via bankruptcy, a borrower must prove that the student loans pose an undue hardship by satisfying the Brunner test requirements, but this is easier said than done. ${ }^{114}$

\section{The Brunner Test}

In 1985, the United States Bankruptcy Court for the Southern District of New York handed down its decision in the matter of Brunner v. New York State Higher Education Services Corporation, which would become the single most influential decision in the context of student loan dischargeability. ${ }^{115}$ Precipitating the case, Marie Brunner waited less than one year after graduating from college before filing for bankruptcy in an attempt to discharge her student loans. ${ }^{116}$ At the time of the court's decision, there was no real standard for student loan discharge under Chapter 7 bankruptcy proceedings, so the federal bankruptcy court devised a test based on criteria other courts used to evaluate similar cases. ${ }^{117}$

The first prong of the test that the court created for whether a borrower could have her student loans discharged through a bankruptcy proceeding, henceforth known as the Brunner test, requires the borrower to show that she is unable to simultaneously make payments on her student loans and achieve the "minimal standard of living" for herself and, if applicable, any of her dependents. ${ }^{118}$ In other words, this first prong of the Brunner test, in which borrowers must establish that repaying student loans creates an undue hardship, places the burden on borrowers to demonstrate that, "given [their] current income and expenses, the necessity of making the monthly loan payment will cause [their] standard of living to fall below a 'minimal' level."119

In Brunner, the borrower was unable to secure employment following her graduation and decided to file for bankruptcy after just eleven months. ${ }^{120}$ If a borrower has no source of income, it is clear that the borrower would be unable to achieve the "minimal standard of living" and make the required monthly payments on the borrower's student loans. ${ }^{121}$ In fact, showing that the borrower has no income demonstrates that the borrower has no realistic ability to either meet loan repayment obligations or achieve a minimal standard of living. ${ }^{122}$ The court opined that "it is not unreasonable to hold that committing the [borrower] to a life of

debt-dischargeability-courts-discuss-limits-of-brunner-test [https://perma.cc/8ED9WGXG].

114. See, e.g., Zack Friedman, Can You Discharge Your Student Loans in Bankruptcy?, Forbes (Jan. 9, 2019, 8:32 AM), https://www.forbes.com/sites/zackfriedman/2019/01/09/stu dent-loans-bankruptcy-discharge/\#53abcee06d56 [https://perma.cc/FA29-W74P].

115. Brunner v. N.Y. State Higher Educ. Servs. Corp. (In re Brunner), 46 B.R. 752

(Bankr. S.D.N.Y. 1985), aff'd, 831 F.2d 395 (2d Cir. 1987) (per curiam).

116. See id. at 753.

117. Id. at 753,756 .

118. Id. at 754 .

119. Id.

120. Id. at 753,757 .

121. Id. at 757 .

122. Id. 
poverty for the term of the loan-generally ten years-imposes 'undue' hardship." 123 However, the issue with this prong alone-and the reasoning behind the introduction of the second prong of the Brunner testrests with the court's opposition to speculating about what the borrower's future financial state will be. ${ }^{124}$

The second prong of the Brunner test turns on whether the borrower's hardship is likely to persist for "a significant portion of the repayment period of the [student] loan." 125 This second prong works as an extension of the first prong because at the time the Brunner decision was rendered, a majority of courts required "more than a showing on the basis of current finances." 126 In a decision a few years prior to Brunner, another judge in the same bankruptcy court delivered an opinion that clarified dischargeability standards, stating that "dischargeability of student loans should be based upon the certainty of hopelessness, not simply a present inability to fulfill financial commitment." 127 This language has been construed to require that borrowers show "unique" or "exceptional" circumstances before their student loans can be discharged via bankruptcy. ${ }^{128}$ Thus, this is the element of the Brunner test which places a very high-if not functionally impossible-bar for borrowers to clear in order to have their student loans discharged in bankruptcy proceedings. ${ }^{129}$

In Marie Brunner's case, the bankruptcy court determined that nothing in the record supported a finding that it was likely that she would continue to be unemployed for a significant period of the loan. ${ }^{130}$ In addition, the court found that nothing in the record alleged that the borrower was

123. Due to the fact that the borrower was unemployed, and her only source of income was government assistance, it is clear that this prong would be satisfied. See id. at 752, 757.

124. Id. at $754-55$.

125. Id. at 755 .

126. Id. (discussing that predicting the future is uneasy based on an "extrapolation of present needs").

127. See Briscoe v. Bank of N.Y. (In re Briscoe), 16 B.R. 128, 131 (Bankr. S.D.N.Y. 1981) (discussing that the borrower is required to demonstrate that the current inability to pay will extend for a significant portion of the repayment period of the loan).

128. Circumstances that are considered "unique" or "exceptional" include illness, a lack of usable job skills, or the existence of a large number of dependents. See, e.g., In re Norman, 25 B.R. 545, 549-50 (Bankr. S.D. Cal 1982); Seibert v. U.S. Gov't Dep't of Health Educ. \& Welfare (In re Siebert), 10 B.R. 704, 705 (Bankr. S.D. Ohio 1981); Clay v. Westmar Coll. (In re Clay), 12 B.R. 251, 254 (Bankr. N.D. Iowa 1981).

129. While data on student loan discharge in bankruptcy proceedings is not widely available or current, the number of borrowers who have been able to meet this bar is vanishingly small:

Only 29 of 72,000 student loan borrowers with active bankruptcy filings in 2008 succeeded in getting a full or partial discharge of their student loans . . . That's $0.04 \%$, or odds of about 1 in 2,500. You're more likely to die of a heart attack or of cancer than to get your student loans discharged in bankruptcy.

Mark Kantrowitz, How to Discharge Your Student Loans in Bankruptcy, SAving for Coll. (Feb. 28, 2020), https://www.savingforcollege.com/article/how-to-discharge-your-stu dent-loans-in-bankruptcy [https://perma.cc/8SXH-AAVT]. But see Iuliano, supra note 73 (suggesting that this statistic appears dismal precisely because most borrowers do not seek discharge in bankruptcy proceedings and that they would have success of getting at least partial relief if they did).

130. See Brunner, 46 B.R. at 758. 
faced with the aforementioned unique or exceptional circumstances that demonstrated "a total incapacity now and in the future to pay [her] debts for reasons not within [her] control."131

The third and final prong of the Brunner test asks if the borrower made "good faith efforts" to repay the borrower's student loans. ${ }^{132}$ This requirement addresses the court's concern about unscrupulous borrowersof which there are likely very few ${ }^{133}$ — using the bankruptcy process to discharge all of their debt obligations by virtue of a singular process that relies on their student loan debt-to-income ratios. For example, the court in Brunner stated its intention - and that of lawmakers-" to forestall students, who frequently have a large excess of liabilities over assets solely because of their student loans, from abusing the bankruptcy system to shed [their] loans." 134 Perhaps this requirement is owing to the particular circumstances of the case before the court; in Brunner, the court was faced with a borrower who demonstrated that she made "virtually no attempt to repay." 135 In addition, the court highlighted that the borrower did not seek any alternative remedies, such as deferment, before requesting a discharge via bankruptcy. ${ }^{136}$ Thus, perhaps rightly so, the court seemed to make an example of Marie Brunner by implementing the good faith prong of its test for undue hardship. ${ }^{137}$ Problematically, scholars have observed that this test is inconsistently applied and used in myriad ways to prevent other borrowers-whose cases were more deserving of discharge-from realizing debt relief via bankruptcy proceedings. ${ }^{138}$

\section{B. The Practical Prohibition Against Student Loan Discharge VIA BANKRUPTCY}

Ostensibly, the Brunner test created a flexible standard that provided a mechanism for borrowers to discharge their student loans in bankruptcy proceedings. ${ }^{139}$ Its original intention may have been pure in that the test

131. Id. (alteration in original) (quoting In re Rappaport, 16. B.R. 615, 617 (Bankr. D. N.J. 1981)).

132. Id. at 755 .

133. The myth of the unscrupulous borrower is unsubstantiated. See, e.g., Pardo, supra note 17 , at 2143 .

134. Brunner, 46 B.R. at 755; see 11 U.S.C. $\$ 523(a)(8)$.

135. Brunner, 46 B.R. at 758.

136. Id. But some courts have held that-for purposes of meeting the good faith requirement-it would be inappropriate to withhold discharge from a borrower based on her unwillingness to enter into an income-driven repayment plan instead of bankruptcy. See, e.g., Krieger v. Educ. Credit Mgmt. Corp., 713 F.3d 882, 884 (7th Cir. 2013).

137. Brunner, 46 B.R. at 758.

138. See Pardo \& Lacey, supra note 110, at 197 (noting that the Brunner test has given bankruptcy courts "free rein to infuse subjectivity into what should be a straightforward financial calculation"); see also Taylor \& Sheffner, supra note 17, at 332 (concluding that bankruptcy courts' use of the Brunner test "allow[s] for judicial subjectivities to influence outcomes"); Bruckner et al., supra note 90, at 185-86 ("Keldric Dante Mosley was homeless and surviving on food stamps and disability benefits from the United States Department of Veterans Affairs when he asked the bankruptcy court to relieve him of his $\$ 45,00$ student loan burden.").

139. Brunner, 46 B.R. at 758. 
was implemented to avoid abuse of the bankruptcy system by studentborrowers. ${ }^{140}$ However, in reality, the Brunner test has often produced harsh results, leading to its criticism from various contemporary sources. ${ }^{141}$ Although some borrowers were still able to satisfy Brunner's strict test and have their student loans discharged in bankruptcy proceedings, the practical prohibition against student loan discharge via bankruptcy was seemingly solidified after $2005 .{ }^{142}$

If there was any question about the dischargeability of student loan debt, it was answered in the negative when Congress passed the Bankruptcy Abuse Prevention and Consumer Protection Act (BAPCPA). ${ }^{143}$ BAPCPA was enacted to stop debtors from abusing the Bankruptcy Code more broadly, but in doing so, it explicitly exempted both private and federal student loans from being dischargeable in bankruptcy. ${ }^{144}$ As with the Brunner court's reasoning, the rationale for the Act was to prevent borrowers, including student loan borrowers, from exploiting and abusing existing bankruptcy laws for their own pecuniary gain. ${ }^{145}$ But its provisions, working in tandem with federal bankruptcy courts' strict application of the Brunner test, has all but foreclosed student loan dischargeability to many non-exploitative student loan borrowers who might otherwise have benefitted from their student loans being discharged in bankruptcy. ${ }^{146}$ Clearly, the costs outweigh the benefits of the Brunner test, given its misapplications. And to the extent that the test is chipped away or replaced altogether by subsequent bankruptcy court decisions, a new test could emerge that would hopefully net student loan borrowers with meaningful relief, even if it could bring an end to the presumption that SLABS are a sure bet for investors. ${ }^{147}$

140. Id.

141. See John Patrick Hunt, Consent to Student Loan Bankruptcy Discharge, 95 IND. L.J. 1137, 1170-71 (2020); Bruckner et al., supra note 90, at 233-48 (discussing various reform proposals).

142. 11 U.S.C. $\S 523(\mathrm{a})(8)$. The 2005 amendment to this code section broadened the kinds of federal and private student loans that cannot be discharged in bankruptcy, absent a finding of the borrower's undue hardship. See also Friedman, supra note 114.

143. Friedman, supra note 114.

144. Id.

145. Id. (discussing that a major concern was that allowing discharge of student loans via bankruptcy would incentivize people borrowing massive sums of money to attend school and then, shortly after receiving their degree, file for bankruptcy to have those loans discharged).

146. Alexei Alexandrov \& Dalié Jiménez, Lessons from Bankruptcy Reform in the Private Student Loan Market, 11 Harv. L. \& Pol'y Rev. 175, 176 (2017) (exploring the effect of the 2005 bankruptcy amendments on the private student loan market and suggesting that "bankruptcy reform failed miserably at helping students").

147. "In Brunner evaluations, courts tend to disagree on what constitutes a 'minimal standard of living.' . . . Courts also vary substantially in determining what evidence debtors are required to show to establish that their situation will persist. . . . However, although scholars have advocated for judicial uniformity for over a decade, no such uniformity has emerged." Bruckner et al., supra note 94, at 196, 241-42. 


\section{The First Real Crack in the Brunner Test's Armor}

Three recent cases decided in the United States Bankruptcy Court for the Southern District of New York, as well as by two separate three-judge panels of the United States Court of Appeals for the Fifth Circuit and the Tenth Circuit, directly confront the legacy of the Brunner test and cast doubt on its near-total prohibition of the discharge of student loan debt in bankruptcy proceedings. We examine this emerging but swift change in bankruptcy jurisprudence through the illustrative case of Rosenberg $v$. New York State Higher Education Services Corp. ${ }^{148}$

Like many students, Kevin Rosenberg began borrowing money for his educational expenses during his undergraduate education from 1993 to 1996. ${ }^{149}$ Subsequently, he enlisted in the Navy, where he was on active duty for the next five years between 1996 and 2001. ${ }^{150}$ After completing his military service, Rosenberg attended law school from 2001 through 2004. ${ }^{151}$ After graduating, his student loan balance, including both undergraduate and graduate school debt, was $\$ 116,464.75 .152$ In June 2018, almost twenty-five years after taking out his first student loan, Rosenberg filed for bankruptcy. ${ }^{153}$ At the time that his case was heard by a federal bankruptcy court, Rosenberg owed $\$ 221,385.49$ in student loan debt, which was accruing interest at a rate of $3.38 \%$ per annum. ${ }^{154}$

On January 7, 2020, Rosenberg emerged victorious after Chief U.S. Bankruptcy Judge for the Southern District of New York, Cecelia Morris, declared that his substantial student loans were dischargeable in the bankruptcy proceeding. Interestingly, Chief Judge Morris rendered her decision using the Brunner test. ${ }^{155}$ Chief Judge Morris criticized her peers in their harsh applications of the Brunner test, stating that "[o]ver the past 32 years, many cases have pinned on Brunner punitive standards that are not contained therein." 156 In her opinion, Chief Judge Morris continued to say that in the three decades since the Brunner decision was rendered, the dictum in the cases using the Brunner test have been "applied and reapplied so frequently in the context of Brunner that they have subsumed the actual language of the Brunner test." 157 This speaks to the reality that the Brunner test has taken on a life of its own, which the U.S. Bankruptcy Court for the Southern District of New York sought to alter in Rosenberg, overturning aspects of its earlier precedent in Brunner.

148. Rosenberg v. N.Y. State Higher Educ. Servs. Corp. (In re Rosenberg), 610 B.R. 454, 457 (Bankr. S.D.N.Y. 2020).

149. Id.

150. Id.

151. Id.

152. Id.

153. Id.

154. Id.

155. Id. at 456

156. Id. at $458-59$.

157. Id. at 459 . 
2. Application of the Brunner Test in Rosenberg v. New York State Higher Education Services Corp.

When evaluating the first prong of the Brunner test, the court must determine whether borrowers cannot maintain, based on current income and expense, a "minimal" standard of living for themselves and their dependents if they are forced to repay their loans. ${ }^{158}$ At the time of the filing, Rosenberg's income was limited to $\$ 2,456.24$ per month, which could not cover his $\$ 4,005.00$ in monthly expenses. ${ }^{159}$ This meant that Rosenberg had a negative net income of over $\$ 1,500$ when he filed for bankruptcy. ${ }^{160}$ These facts were sufficient to prove that Rosenberg was, based on his current income, unable to immediately pay back his student loan in full. ${ }^{161}$ The court used the "pay in full" metric because the borrower was in default at the time of the proceeding and thus was not enrolled or eligible for any kind of repayment plan. ${ }^{62}$ Since Rosenberg had a negative income each month and no present ability to repay his student loans, the court found that he successfully satisfied the first prong of the Brunner test. 163

Next, the court turned to a discussion of whether additional circumstances existed that indicated Rosenberg's state of affairs was likely to persist for a significant portion of the repayment period of his student loans. ${ }^{164}$ The court noted that the Brunner test does not require the court to make a determination that the petitioner's state of affairs will persist forever, nor does it require a determination of whether the borrower's state of affairs was created by "choice." 165 In this case, Rosenberg's repayment period had already ended, and he was in default. 166 As a result, at the time of filing for bankruptcy, Rosenberg was required to pay the $\$ 221,385.49$ in full. ${ }^{167}$ The court found that it was obvious that this state of affairs would persist for the remainder of the repayment period because the repayment period had already ended, and the total amount of the loan was due. ${ }^{168}$ In conclusion, the court found that Rosenberg successfully satisfied the second prong of the Brunner test. ${ }^{169}$

158. Id.

159. $I d$. at 460 .

160. Id. (noting that Rosenberg's net income at the time of filing was $-\$ 1,548.74$ ).

161. Id.

162. For a borrower to become eligible for a monthly repayment plan, he would first need to agree "to make nine voluntary, reasonable and affordable monthly payments within 20 days of the due date, and make all nine payments during a period of 10 consecutive months." See id. (noting that it would have been impractical to discuss a rehabilitation option in this case, since Rosenberg already had a negative income each month notwithstanding an effort to rehabilitate his student loans).

163. Id. at $460-61$.

164. Id. at 461 .

165. Id.

166. Id.

167. $I d$.

168. Id.

169. Id. 
In examining the last prong of the test, the court must determine whether or not the borrower has made good faith efforts to repay the loan. ${ }^{170}$ In evaluating this prong, the court can only look to borrowers' past behavior in their effort to repay their student loans. ${ }^{171}$ As of 2018, thirteen years after his student loan payments first became due, Rosenberg had only missed sixteen payments. ${ }^{172}$ However, it is important to note that Rosenberg's student loan was in deferment or forbearance for the ten-year period after they became due, from about April 2005 through April 2015. ${ }^{173}$ As discussed in earlier sections of this Article, deferment and forbearance stall the borrower from making any payments. ${ }^{174}$ Thus, as of 2015-when the forbearance or deference period ended-Rosenberg was completely current on his student loan debt, and no payments were due on his loans. ${ }^{175}$

From April 2015 through January 2018, Rosenberg entered into a series of repayment plans in addition to a forbearance period from April 2016 through October 2016. ${ }^{176}$ Over "the 26 months that [he] was responsible for making payments" on his outstanding student loan, Rosenberg "made 10 payments, in varying amounts." 177 In fact, the court highlighted that Rosenberg made payments whenever he could, including the period when his account was in forbearance, meaning that he made payments even though no payments were due at that time. ${ }^{178}$ In January 2018, Rosenberg entered default on his outstanding student loan. ${ }^{179}$ Ultimately, the court calculated the rate of payment, taking into consideration the months in which payments were due compared with how many payments were actually made. ${ }^{180}$ Finding that a $40 \%$ payment rate over a thirteenyear period was a satisfactory showing of Rosenberg's good faith effort to repay his student loan, the court found that the third and final prong of the Brunner test was satisfied. ${ }^{181}$

Concluding that all of the elements of the Brunner test were met, the court found that Rosenberg successfully satisfied the undue hardship standard. ${ }^{182}$ As a result, the court ordered that all of Rosenberg's student

170. Id.

171. Id. (noting that it is "inappropriate" for the court to consider the borrower's reasons for filing for bankruptcy, how much debt the borrower has, or if the borrower rejected any options for repayment).

172. Id.

173. Id. at 462 .

174. See supra Section I.C.1.

175. Rosenberg, 610 B.R. at 462.

176. Id.

177. Id.

178. Id.

179. Id.

180. Id. (noting that ten payments over twenty-six months where Rosenberg was required to make a payment equals "approximately a $40 \%$ rate of payment over a thirteenyear period").

181. Id. (discussing how Rosenberg "did not sit back for 20 years but made a good faith effort to repay his [s]tudent [1]oan").

182. See id.; 11 U.S.C. $\$ 523(\mathrm{a})(8)$. 
loan debt be discharged on the grounds that it imposed an undue hardship on him. ${ }^{183}$

While it bears mentioning that the case has been appealed, the cry of scholars and borrowers alike for a turn away from both the stricturesand vagaries-of the Brunner test, which has resulted in more harm than good, make the Rosenberg case the best shot at overturning the Brunner decision and replacing it with a test that more closely aligns with borrower-friendly principles in consumer bankruptcy proceedings. ${ }^{184}$ Even if the bankruptcy courts are slow to discard the Brunner test requirements-or the test's reinterpretation under Rosenberg-the Rosenberg decision could yield changes in bankruptcy courts. Borrowers have rarely sought to have their loans discharged in bankruptcy because they either were unaware that they could do so or thought they were unlikely to be granted relief if they did. The significant media attention that the Rosenberg decision has received undoubtedly changes the informational asymmetry confronting borrowers who find themselves unable to make their student loan payments. ${ }^{185}$ Armed with this information and emboldened by the favorable decision rendered in Rosenberg, many more borrowers may now seek to have their student loans discharged in bankruptcy. And many federal courts may agree with the Rosenberg court's application of the undue hardship test. Indeed, at the time of this Article's publication, at least two federal circuit courts of appeal have determined, like the U.S. Bankruptcy Court for the Southern District of New York did in reexamining its Brunner holding in Rosenberg, that student loans are indeed dischargeable in bankruptcy proceedings. ${ }^{186}$ That these cases were decided in the borrowers' favor, not just in bankruptcy court but in two federal

183. Rosenberg, 610 B.R. at 462.

184. Rosenberg v. NY State Higher Education Services Corporation et A Bankruptcy Court Docket Sheet, DocketBiRD, https://www.docketbird.com/court-cases/Rosenberg-vNY-State-Higher-Education-Services-Corportion-et-A/nysb-4:2018-ap-09023 [https:// perma.cc/XMK4-9QRM].

185. See Adam S. Minsky, A Judge Just Wiped out This Man's $\$ 221,000$ in Student Debt, Forbes (Jan. 22, 2020, 11:52 AM), https://www.forbes.com/sites/adamminsky/2020/01/22/ajudge-just-wiped-out-this-mans-221000-in-student-debt/\#53549ccc3782 [https://perma.cc/ 98T3-47VT]; Steven Chung, An Interview With Kevin Rosenberg Where He Explains How He Successfully Discharged His Student Loans in Bankruptcy Court, Aвove L. (Jan. 15, 2020, 10:32 AM), https://abovethelaw.com/2020/01/an-interview-with-kevin-rosenbergwhere-he-explains-how-he-successfully-discharged-his-student-loans-in-bankruptcy-court/ [https://perma.cc/SAX7-8NWP]; Samantha Fields, Judge Rejects "Myths" That It's Impossible to Get Rid of Student Loans in Bankruptcy, MarketPlace (Jan. 15, 2020), https:// www.marketplace.org/2020/01/15/judge-rejects-myths-that-its-impossible-to-get-rid-of-stu dent-loans-in-bankruptcy/ [https://perma.cc/X6A6-Y6BX]; Debra Cassens Weiss, Law Grad Wins Discharge of His Student Debt in Opinion Criticizing 'Punitive Standards', ABA J. (Jan. 9, 2020, 10:25 AM), https://www.abajournal.com/news/article/law-grad-wins-dis charge-of-his-student-debt-in-opinion-criticizing-punitive-standards [https://perma.cc/ Y3UL-XPGC].

186. See, e.g., McDaniel v. Navient Sols., 973 F.3d 1083 (10th Cir. 2020) (dealing with a married couple who entered a Chapter 13 bankruptcy filing to discharge their combined student loan debt among other debt); Crocker v. Navient Solutions, 941 F.3d 206 (5th Cir. 2019) (resolving two individual Chapter 7 bankruptcy filings in different jurisdictions and discharging the borrowers' private student loans). 
courts of appeals, signals a marked shift in bankruptcy jurisprudence in a very short time. ${ }^{187}$

Since the start of the COVID-19 pandemic, unemployment rates have dramatically increased and available jobs have become increasingly contingent and precarious, while wages have stagnated and may remain stagnant for many months to come. ${ }^{188}$ Thus, it is entirely foreseeable that many student loan borrowers' expenses will outstrip their earnings. Regardless of how long this state of affairs lasts, this situation will likely result in default for a significant proportion of borrowers, many of whom will have made good faith efforts to repay their loans until March 2020. These borrowers will find themselves in circumstances that are similar, if not functionally identical, to that of Kevin Rosenberg. Thus, the spate of cases in which federal courts have concluded that student loans are dischargeable in bankruptcy proceedings-in the last year alone-not only impacts borrowers seeking to discharge their loans in bankruptcy but also impacts the economy at large through the SLABS market.

\section{STUDENT LOAN ASSET-BACKED SECURITIES}

\section{A. SLABS: A Foundation in Mortgage-Backed Securities}

In the wake of the 2008 recession, experts were nearly unanimous in placing the blame of the economic downturn on lenders who issued subprime mortgages and the subsequent investment in residential mortgagebacked securities. ${ }^{189}$ Residential mortgage-backed securities-or, more generally, asset-backed securities-are investments that make money based on the revenue received from some underlying asset, and that un-

187. See Charles M. Tatelbaum, Christina V. Paradowski \& Brittany L. Hynes, $A$ Changing Tide in the Bankruptcy Discharge of Certain Student Loan Debt, LAw.COM (Sept. 29, 2020, 10:19 AM), https://www.law.com/dailybusinessreview/2020/09/29/a-changing-tidein-the-bankruptcy-discharge-of-certain-student-loan-debt/ [https://perma.cc/U8HX-9R2F]; Rebecca Safier, Student Loan Bankruptcy Discharge Ruling May Signal Big Boon to Borrowers, Student Loan Hero (Sept. 9, 2020), https://studentloanhero.com/featured/stu dent-loan-bankruptcy-discharge-ruling/ [https://perma.cc/4DHE-93W4].

188. See, e.g., Rakesh Kochhar, Unemployment Rose Higher in Three Months of COVID-19 Than It Did in Two Years of the Great Recession, Pew Rsch. Ctr. (June 11, 2020), https://www.pewresearch.org/fact-tank/2020/06/11/unemployment-rose-higher-inthree-months-of-covid-19-than-it-did-in-two-years-of-the-great-recession/ [https:// perma.cc/Q6GW-9L4X]; Mary Baker, 9 Future of Work Trends Post-COVID-19, GARTNER (June 8, 2020), https://www.gartner.com/smarterwithgartner/9-future-of-work-trendspost-covid-19/ [https://perma.cc/2LBX-KP8R] (noting that "32\% of organizations are replacing full-time employees with contingent workers as a cost-saving measure"); Worker Exposure Risk to COVID-19, Occupational SAfETy \& Health Admin., https:// www.osha.gov/Publications/OSHA3993.pdf [https://perma.cc/9CQZ-J89W] (listing a broad set of employment sectors as carrying at least medium risk of employees within those sectors contracting COVID-19); Karen Ho, The COVID-19 Pandemic Will Be a Disaster for Wages, Even Once We All Go Back to Work, Quartz (May 15, 2020), https://qz.com/ 1856358/the-covid-19-pandemic-will-be-a-disaster-for-us-wages/ [https://perma.cc/ZF9JVU3C].

189. See, e.g., Eric Rauchway, The 2008 Crash: What Happened to All That Money?, History (Feb. 1, 2019), https://www.history.com/news/2008-financial-crisis-causes [https:// perma.cc/Y8WD-NEGY]. 
derlying asset, typically, is debt. ${ }^{190}$ Aside from the obvious value to investors and potential investors, lenders are able to finance future loans with the funds obtained through the sale of these securities. ${ }^{191}$ When a company creates a security, it will typically bundle a group of several thousand debts and sell those debts to a financial firm. ${ }^{192}$ After the financial firm acquires ownership of the debts, that firm will bundle thousands of individual debts into one investment and sell shares for investors to buy. ${ }^{193}$ These investments yield returns for investors when borrowers make payments on their debts. ${ }^{194}$

As the title of this Article hints, there are many similarities between the mortgages during the 2008 recession and the current status of student loans. However, the two differ with respect to the debt obligations they create. Lenders extend mortgages because they are secured by collateral; typically, the real property itself is considered as collateral in the transaction. As such, if a borrower defaults on the borrower's mortgage, the lender is then able to seize and sell the property to settle the borrower's debt obligation. Before the 2008 recession, many mortgage loans were issued based on the expectation of future increases in value to the home and, therefore, were originally undersecured, meaning that the loan to value ratio was, in some cases, $100 \%$ at signing. However, when the housing bubble burst, the values of the homes dropped drastically, causing loans that were initially oversecured to become undersecured and loans that were originally undersecured to become dramatically more so, due to the homes' depreciation in value. When loans are undersecured and the borrower defaults, lenders are in a first-loss position.

By way of an illustration, assume that a borrower went to a lender to obtain a nonrecourse residential mortgage loan in 2006. The value of the home was $\$ 500,000$ at the time of the purchase. The borrower made a $20 \%$ down payment on the home, equal to $\$ 100,000$. The borrower looked to the lender to provide the additional $\$ 400,000$ for the borrower

190. See, e.g., Eric Reed, Should You Invest in Student Loan Asset-Backed Securities?, TheSTREeT (May 20, 2017, 1:20 PM), https://www.thestreet.com/personal-finance/shouldyou-invest-in-student-loan-asset-backed-securities-14142296 [https://perma.cc/DSG6NPS6] (noting that other revenue sources can be used, including an example of a "movie studio [that] created bonds around film profits").

191. For an in-depth analysis of how securitization funds new lending, and thus offloads risk borne by lenders, see Christopher K. Odinet, Securitizing Digital Debts, 52 ArIz. State L.J. 477, 477 (2020) [hereinafter Odinet, Securitizing Digital Debts] (noting that fintech credit firms routinely securitize loans that they originate, allowing them to access capital markets and, in turn, "further the spread of borrower capital and credit risk"); Christopher K. Odinet, The New Data of Student Debt, 92 S. CAL. L. Rev. 1617, 1617-18 (2019) [hereinafter Odinet, The New Data of Student Debt] (discussing how fintech lenders are expanding their online lending activities to help student loan borrowers finance or refinance student loan debt-which they then package as SLABS-and the stratification issues that the use of education-based data creates, including discriminatory lending practices that harm minority groups); Christopher K. Odinet, Consumer Bitcredit and Fintech Lending, 69 AlA. L. REv. 781, 783 (2018) (focusing on how fintech lenders securitize digital debt, among other things).

192. Odinet, Securitizing Digital Debts, supra note 191, at 499.

193. Id at 502 .

194. Id. 
to purchase the home, needing to secure a mortgage loan for the same amount. When evaluating whether to make a loan, the lender must examine the value of the asset that will become the collateral securing the loan. Here, the collateral for the mortgage was the home itself. The vast majority of lenders would have issued this loan because it was oversecured by $\$ 100,000$, providing the lender with an equity cushion equal to the borrower's downpayment. However, when home values started to fall drastically in 2008, the value of the borrower's home decreased to $\$ 350,000$. Now, instead of the bank having a $\$ 100,000$ equity cushion, the lender is faced with a $\$ 50,000$ deficit on a now undersecured loan. Eventually, if the borrower defaulted, the borrower would forfeit the collateral securing the mortgage loan-the borrower's home-in exchange for being released from the mortgage obligation. Once the lender forecloses, it owns the home but also suffers a $\$ 50,000$ loss. Generally, businesseslending institutions included-are expected to incur some losses. However, lenders are unable to operate and unable to support the economy when they consistently operate at a loss, as in the case of a multi-year wave of mortgage loan defaults. The rate of default on residential mortgages reached its peak in 2010 when $23 \%$ of all homes in the United States were worth less than their mortgages and slightly under half of these homeowners defaulted on their mortgage loans. ${ }^{195}$

In the time leading up to the 2008 recession, lenders overextended themselves by lending to subprime borrowers, or those who may have difficulty in maintaining the repayment schedule, as reflected in their credit scores. ${ }^{196}$ These mortgages were awarded so easily because the lenders had no intention of keeping the loans. ${ }^{197}$ Instead, these lenders became eager to sell off mortgages to banks, which would in turn bundle these debts and market them as securities to hopeful investors. ${ }^{198}$ At the time, mortgage-backed securities had been solid investments and had yielded consistent returns on investment. ${ }^{199}$ However, risky mortgage lending practices turned residential mortgage-backed securities into risky investments when mortgage borrowers were ultimately unable to repay their debts. ${ }^{200}$

195. See Weekly Economic \& Financial Commentary, Wells Fargo Econ. Rsch. (Sept. 17, 2010), https://www08.wellsfargomedia.com/downloads/pdf/com/research/eco nomic_commentary/efc09172010.pdf [https://perma.cc/8KAJ-HXG5] (providing the statistic for "underwater" home values); see also Jennifer Rudden, Mortgage Delinquency Rates in the U.S. 2000-2018, Statista (Feb. 21, 2020), https://www.statista.com/statistics/205977/ us-federal-housing-administration-loans-since-1990/ [https://perma.cc/V2VB-LDS5] (listing the residential mortgage default rate at $9.3 \%$ in 2010).

196. See Edward M. Gramlich, Governor, Remarks at the Financial Services Roundtable Annual Housing Policy Meeting, Chicago, Illinois (May 21, 2004), https:// www.federalreserve.gov/boarddocs/Speeches/2004/20040521/default.htm [https://perma.cc/ 7M8P-GR7U].

197. See, e.g., Rauchway, supra note 189.

198. Id.

199. Id.

200. Id. 
The 2008 recession was particularly devastating because residential mortgages were-and still are-the country's largest source of consumer debt, but student loan debt now follows closely behind. However, although student loans can be issued to nearly anyone seeking to attend a higher education institution and do not offer lenders the same kind of collateral that mortgages do, student loans arguably carry less risk than other loans because of the federal guarantee that many student loans enjoy and because the enactment of BAPCPA effectively precluded student loans from being discharged in bankruptcy. ${ }^{201}$ Thus, because student loans carry relatively low risk for lenders relative to other forms of lending, the student loan lending industry-and, in the same vein, the student loan asset-backed securities market-has grown considerably since its inception, due in part to demand.202

\section{B. A Low-Risk InVestment?}

SLABS are a relatively new-fangled investment vehicle but their origins can be traced to the Securities and Exchange Commission's adoption of Rule 3a-7 of the Investment Company Act of 1940. ${ }^{203}$ These rules allowed security-issuing companies to avoid asset registration and regulatory oversight. Beginning in the early 1990s, student loan companies started issuing securities and quickly turned a profit from them, leading to their increased popularity over the last two decades. ${ }^{204}$ In fact, the demand for these investments outweighs their supply. ${ }^{205}$ In total, approximately $\$ 600$ billion worth of SLABS have been issued since their creation in 1992.206 These SLABS have been issued to investors at rates that outpace other asset-backed securities sectors and include new private loans made by Sallie Mae and newcomers like SoFi and Navient (a Sallie-Maespinoff), as well as existing federal loans issued under the Federal Direct Loan Program that have been privately refinanced and loans made under the FFELP that continue to be securitized into asset-backed securities

201. See, e.g., 2005 Law Made Student Loans More Lucrative, NPR (Apr. 24, 2007, 4:00 PM), https://www.npr.org/templates/story/story.php?storyId=9803213 [https://perma.cc/ C5XF-ETEW].

202. Id.

203. Investment Company Act of 1940, 15 U.S.C. $\S 80 a-3(a)-(b) ; 17$ C.F.R. $§ 270.3 a-7$ (2020). Specifically, commodity pool operators, under Section 3(a), and companies engaged in business other than investing, holding, or trading securities, under Sections 3(b)(1) and 3(b)(2), are exempt from the Act's registration requirements. See Investment Company Registration and Regulation Package, U.S. Sec. \& ExсH. Comm'N (Feb. 19, 2013), https://www.sec.gov/investment/fast-answers/divisionsinvestmentinvcoreg 121504htm.html\#P91_16908 [https://perma.cc/JG32-472L].

204. See, e.g., Eli J. Campbell, Wall Street Has Been Gambling with Student Loan Debt for Decades, Common Dreams (Oct. 26, 2019), https://www.commondreams.org/views/ 2019/10/26/wall-street-has-been-gambling-student-loan-debt-decades-0 [https://perma.cc/ AU68-RJ3V].

205. See, e.g., Reed, supra note 190 ("Mike VanErdewyk, the founder and CEO of ... a private student loan solutions provider" stated that his firm has "a billion dollars more in demand [for SLABS] than [his firm can] supply right now.").

206. See, e.g., Campbell, supra note 204. 
offerings, despite the discontinuation of FFELP in $2010 . .^{207}$

Like ordinary bonds, SLABS deliver investors scheduled coupon payments and are generally considered to be relatively safe investments for two reasons. ${ }^{208}$ First, because SLABS diversify default risk for lenders across many investors, lenders can issue more and larger loans, investors can hold a diversifying investment vehicle, and lenders can create consistent cash flow to repay investors through their scheduled coupon payments. ${ }^{209}$ The second reason only applies to some student loans marketed as SLABS, but if the SLABS investor is not discerning, the investor may think it applies to all loans in a SLABS class. The majority of student loans-more than $\$ 1.4$ trillion-are guaranteed by the federal government-up to $97 \%$ of the principal on the loan plus interest payments-in the event that the student loan borrower defaults. ${ }^{210}$ This guarantee ensures that most, if not all, of the underlying collateral will be returned to the lender in the event of a borrower's default. ${ }^{211}$ That said, private loans do not come with the same guarantee, but these loans represent a small proportion-around $10 \%$ - of the student loan sector. ${ }^{212}$ The underlying presumption that student loans are federally guaranteed-because the overwhelming majority of loans are federally guaranteed-gives rise to the misconception that most loans included in SLABS come with federal backing; however, the reality is that they do not. New privately issued loans do not have federal backing, nor do loans issued by the federal government through its Federal Direct Loan Program once they have been consolidated with a private lender. ${ }^{213}$ In fact, Federal Direct Loans

207. Douglas Gimple, The Evolution of the Asset-Backed Securities Market, DiAmond Hill (Nov. 2018), https://www.diamond-hill.com/the-evolution-of-the-asset-backed-securi ties-market/ [https://perma.cc/A6U6-ZNMT]; see Campbell, supra note 204.

208. See, e.g., S\&P Municipal Bond Student Loan Index, S\&P Dow Jones Indices, https://us.spindices.com/indices/fixed-income/sp-municipal-bond-student-loan-index?fbclid=IWAR0OLfGnwurmqlOcvre_kVsYjzD014nOUEViPoGD5Djyc2ohkZxETVc5ZXg [https://perma.cc/484W-7XQY\#overview] (noting the performance of the student loan sector in the S\&P Municipal Bond Index).

209. See Du, supra note 12 .

210. See Stephanie Lee \& Max Egan, Student Loans and Student Loan Asset-Backed Securities: A Primer, Mondaq (June 23, 2009), https://www.mondaq.com/unitedstates/Liti gation-Mediation-Arbitration/81108/Student-Loans-And-Student-Loan-Asset-Backed-Se curities-A-Primer [https://perma.cc/R9VC-PDSW].

211. Id. (noting that this guarantee protects the lender but not necessarily the SLABS holder).

212. See id.; see also Odinet, The New Data of Student Debt, supra note 191.

213. See, e.g., Dave Dahlen, Loan Consolidation: What's the Big Deal?, Mayo Found., https://www.ohe.state.mn.us/pdf/loanConsolidation.pdf [https://perma.cc/EEX2-4DND]. That said, SLABS that include private loans and federally issued loans, have been consolidated by private lenders, and carry a AAA rating have historically been eligible as Term Asset-Backed Securities Loan Facility (TALF) collateral-a distinct form of federal-backing. TALF is a program instituted by the Federal Reserve to spur the issuance of assetbacked securities in the wake of the 2008 recession and provides the issuer of asset-backed security a five-year-or-fewer loan to leverage the issuance of more asset-backed securities. See Term Asset-Backed Securities Loan Facility (TALF), FED. RsRv. (Feb. 12, 2016), https://www.federalreserve.gov/regreform/reform-talf.htm [https://perma.cc/5BB9-ZN4R]; see also Bonnie G. Buchanan, Securitization and the Global Economy: History AND Prospects for the Future 91 (2017). TALF support was renewed by the Federal Reserve in March 2020, amidst COVID-19. Cheryl D. Barnes, Scott A. Cammarn, Michael 
issued by the federal government after 2010 are not eligible for securitization and subsequent marketing as SLABS at all, provided that they are not consolidated with a private lender. ${ }^{214}$ The only class of student loans included in SLABS that retains the federal guarantee is the FFELP class of loans, which leads to the assumption that SLABS consisting of FFELP loans carry lower risk than SLABS backed by private loans. ${ }^{215}$

Even before the onslaught of the COVID-19 pandemic, one of the most pressing issues - in general, in higher education, and as it relates to the economy-is that students are increasingly burdened by the rising cost of higher education. ${ }^{216}$ When students borrow larger amounts of money to fund their attendance at a postsecondary education institution, the amount of their student loan debt increases, and yet, the salaries they can expect to earn in the workforce upon completing their studies remain fairly stagnant. ${ }^{217}$ This presents a challenge to the value proposition of higher education and distorts the relationship of student loan debt-as a debt class- to the value of the underlying asset. ${ }^{218}$ In other words, when post-graduate incomes remain stagnant and student loan debt continues to grow, it creates a "bubble" that is waiting to burst. ${ }^{219}$

The entire SLABS market is premised on the fact that SLABS will continue to produce steady returns for their investors, as they have for many years. This expectation is owing, in part, to a misconception that the loans comprising the SLABS are federally guaranteed and are ineligible for discharge via normal bankruptcy procedures. ${ }^{220}$ But both of these assumptions should be called into question. First, student loans have always carried some risk of default, which-in the case of FFELP loans marketed as SLABS - is mitigated by their federal guarantee. However, over the last few months, to say nothing of the days and weeks ahead, the risk incident to investing in SLABS has significantly increased. The same

S. Gambro, David S. Gingold \& Kahn D. Hobbs, COVID-19 Update: Federal Reserve Issues New TALF Term Sheet and Responses to Frequently Asked Questions, NAT'L L. REv. (May 15, 2020), https://www.natlawreview.com/article/covid-19-update-federal-reserve-issues-new-talf-term-sheet-and-responses-to [https://perma.cc/BJM3-66KJ]. As should be made plain by the terms of the program, this program is distinguishable from federal-backing of student loans.

214. See generally Should I Refinance My Federal Student Loan into a Private Student Loan With a Lower Rate?, Consumer Fin. Prot. Bureau (Aug. 8, 2017), https:// www.consumerfinance.gov/ask-cfpb/should-i-refinance-my-federal-student-loan-into-a-pri vate-student-loan-with-a-lower-rate-en-1687/ [https://perma.cc/Z9GG-BZUK].

215. Timothy Bernstein, The Trouble With FFELP ABS: An Explainer, NEw OAK, https://newoak.com/trouble-ffelp-abs-explainer/ [https://perma.cc/9N23-YYYC]; see Campbell, supra note 204 ("There are still roughly $\$ 280$ billion of FFEL loans outstanding, and the largest firms such as Navient and Nelnet still have FFEL loans in their portfolios and have continued to issue FFEL-backed SLABS.").

216. See supra Part I.

217. See Campbell, supra note 204.

218. Id. See generally Kate Sablosky Elengold, The Investment Imperative, 57 Hous. L. Rev. 1, 1 (2019).

219. Id.; see Lee \& Egan, supra note 210; Prentiss Cox, Judith Fox \& Stacey Tutt, Forgotten Borrowers: Protecting Private Student Loan Borrowers Through State Law, 11 U.C. IRVINE L. REV. (forthcoming 2020).

220. See Campbell, supra note 204. 
credit rating agencies that expected SLABS to outperform comparable asset classes one year ago ${ }^{221}$ have now signaled enhanced risk in the sector by downgrading ratings for several billions of dollars of SLABS. ${ }^{222}$ Credit rating agencies now believe that increasing levels of forbearance and default in the loans underlying SLABS impact the SLABS issuer's ability to pay principal to investors by previously-set final maturity dates-this coming only a few months into the economic uncertainty caused by the COVID-19 pandemic. ${ }^{223}$ Although the risk of borrower delinquency or default is nothing new, ${ }^{224}$ in light of present economic realities, "the nation's largest student loan servicers, including Navient . . . have looked to avoid [default risk] either by ... gaining approvals to amend their bond maturity dates, or by borrowing money to repay [their SLABS] investors themselves." 225 Loan servicers have even begun purchasing loans to pay off bond notes. ${ }^{226}$ Thus, the sharp reversal by credit rating agencies is warranted and highlights the fragility of the SLABS market. But it also harkens back to the collapse of the mortgagebacked securities market in 2008 .

Like mortgages before the 2008 recession, "many of the student loans backing [SLABS] have been given to borrowers with [little to] no assessment" of the borrowers' abilities to repay their loans. ${ }^{227}$ And in the case of private loans, in particular, there are entire classes of SLABS backed

221. See, e.g., Selven C. Veeraragoo, Jinwen Chen \& Joseph Grohotolski, Research Announcement: Moody's Refi SLABS Will Likely Outperform Comparable ABS Asset Classes, Moody's (Aug. 29, 2019), https://www.moodys.com/research/Moodys-Refi-SLABSwill-likely-outperform-comparable-ABS-asset-classes-PBS_1192557 [https://perma.cc/ FU4B-E9AR].

222. See, e.g., Jiaoren Wang \& Jinwen Chen, Rating Action: Moody's Downgrades and Places on Review for Downgrade Certain FFELP Student Loan ABS, Moody's (June 3, 2020), https://www.moodys.com/research/Moodys-downgrades-and-places-on-review-fordowngrade-certain-FFELP_PR_425478 [https://perma.cc/Q8VY-W9TP] (discussing Moody's rationale for downgrading \$11 billion worth of SLABS-representing about $13 \%$ of the $\$ 99$ billion worth of FFELP bonds that Moody's rates).

223. See, e.g., Mark W. O'Neil \& John Anglim, Effects of COVID-19 in U.S. Student Loan ABS, S\&P GLOB. Ratings (Apr. 30, 2020), https://www.spglobal.com/ratings/en/re search/articles/200430-effects-of-covid-19-on-u-s-student-loan-abs-11453961 [https:// perma.cc/4M3C-UZ48]; see also Coronavirus Impact Increases Maturity Risk for FFELP $A B S$, Fitch Ratings (Mar. 26, 2020, 4:06 PM), https://www.fitchratings.com/research/ structured-finance/coronavirus-impact-increases-maturity-risk-for-ffelp-abs-26-03-2020

[https://perma.cc/4L46-8GER] ("Currently, approximately $31 \%$ of Fitch's rated portfolio by bond balance falls into [the FFELP] group.").

224. As recently as one year ago, and well before the COVID-19 pandemic, projections of delinquency rates alone "suggest that $40 \%$ of all borrowers are expected to miss payments by 2022." See Stein \& Duvall, supra note 14.

225. See, e.g., Wiltermuth, supra note 72 . A recent class-action lawsuit also alleged that Navient misled FFELP borrowers about their repayment options. See Corrado Rizzi, Class Action Alleges Navient Misled Student Loan Borrowers About FFELP Repayment Options, ClassAction.org, https://www.classaction.org/blog/class-action-alleges-navient-misledstudent-loan-borrowers-about-ffelp-repayment-options [https://perma.cc/7KKH-SSVH] (last updated Oct. 5, 2017).

226. Wiltermuth, supra note 72.

227. Elena J. Despotopulos, The Securitization of Student Loans: How Investors Are Making Money off Your Loans, Ne. U. L. Rev. F. (May 12, 2018), https://nulronlineforum.wordpress.com/2018/05/12/the-securitization-of-student-loans-how-investorsare-making-money-off-your-loans/ [https://perma.cc/HF9J-KZE6]. 
by loans that were issued to borrowers who were unlikely to repay them. For example, SLM Private Education Student Loan 2009-CT Trust, a SLABS product created from loans issued by Sallie Mae, consists of more than 40,000 loans made to students attending unaccredited trade school programs, such as truck-driving school, cosmetology school, and even dog-walking school. ${ }^{228}$ Our mentioning the educational programs attended by the borrowers whose loans backed the SLM Private Education Loan Trust 2009-CT is not meant to disparage these borrowers. It is, however, meant to highlight the risk of default among borrowers of private student loans. Some direct-to-consumer private loan programs, like the programs these borrowers entered into, have suffered annual default rates of more than $60 \%$ in some years, making them among the riskiest loans to back a SLABS issue. ${ }^{229}$ Yet, when the SLM Private Education Student Loan 2009-CT Trust was issued in 2009, Moody's gave the SLABS a rating of "Aaa," the agency's highest rating. ${ }^{230}$ This illustrative example underscores the precariousness of the SLABS sector, which is operating at heightened risk under the current market conditions.

Even with six months of student loan relief provided in the $\$ 2$ trillion package of the CARES Act, there is every reason to believe that skyrocketing unemployment will lead to dramatically increased student loan default rates when the relief ends on December 31,2020.231 A spike in this

228. See SLM Private Education Loan Trust 2009-CT: Monthly Servicing Report, NAVIENT, https://navient.com/assets/about/investors/debtasset/SLM-Loan-Trusts/06-10/ 2009-CT/09CTqt0314c.pdf [https://perma.cc/BY52-DLLS]; Austin C. Smith, The Looming Collapse of Student Loan Asset Backed Securities, Bloomberg L. (Dec. 13, 2017, 2:11 $\mathrm{PM}$ ), https://news.bloomberglaw.com/bankruptcy-law/the-looming-collapse-of-studentloan-asset-backed-securities [https://perma.cc/92PB-MEBG].

229. SLM Private Education Loan Trust 2009-CT: Monthly Servicing Report, supra note 228.

230. Barbara A. Lambotte \& Corey Henry, Rating Action: Moody's Rates SLM Private Education Loan Trust 2009-CT, Moody's (Dec. 11, 2009), https://www.moodys.com/research/Moodys-rates-SLM-Private-Education-Loan-Trust-2009-CT_PR_191847 [https:// perma.cc/ZWE9-PZKX].

231. See Stephanie Aaronson \& Francisca Alba, Unemployment Among Young Workers During COVID-19, BROOKINGS (Sept. 10, 2020), https://www.brookings.edu/research/ unemployment-among-young-workers-during-covid-19/ [https://perma.cc/PL92-WZB3] (identifying how the pandemic has impacted young workers and particularly young people of color); Kochhar, supra note 188 (noting that in the first three months of the pandemic, unemployment rose higher than it did in two years of the 2008 recession); Tony Romm, Americans Have Filed More Than 40 Million Jobless Claims in Past 10 Weeks as Another 2.1 Million Filed for Benefits Last Week, WAsh. Post (May 28, 2020, 1:00 PM), https:// www.washingtonpost.com/business/2020/05/28/unemployment-claims-coronavirus/ [https:// perma.cc/SGJ6-7U3J] (reporting that forty million Americans-over 12\% of the U.S. population-have filed for unemployment in the last ten weeks alone). The CARES Act relief granted for borrowers was slated to end on September 30, 2020, but was extended to December 31, 2020. Compare Zack Friedman, Trump Suspends Student Loan Payments Through December 31, Forbes (Aug. 8, 2020), https://www.forbes.com/sites/zackfriedman/ 2020/08/08/student-loans-suspend-december-31/\#188921725a0e [https://perma.cc/Q5Q3CZM2] (relating that an executive order extended the CARES Act relief for student loan payments until December 31) with Wesley Whistle, A Surprise Benefit for Student Loan Borrowers from the CARES Act, ForBes (Apr. 2, 2020, 10:49 AM), https:// www.forbes.com/sites/wesleywhistle/2020/04/02/a-surprise-benefit-for-student-loan-borrowers-from-the-cares-act/\#1d43d44a4909 [https://perma.cc/ME68-SYSB] (discussing the 
default rate in a short period of time will undoubtedly strain SLABS issuers' ability to pay their investors on a scale that has never before been seen. Also, borrowers, whose loans back SLABS, are already finding themselves faced with mounting expenses that impact their ability to make future loan payments. ${ }^{232}$ Many will default, and they could turn to the bankruptcy courts for relief. It has been said that the law moves slowly, but other courts will surely follow the lead of the two federal circuit courts of appeal and the U.S. Bankruptcy Court for the Southern District of New York in its Rosenberg decision-allowing borrowers to discharge their student loans via the bankruptcy process-particularly if the Second Circuit Court of Appeals affirms the Rosenberg decision. ${ }^{233}$ Both of these possibilities - if not likelihoods-would ignite the inflammable student loan sector and place the safe investment tag on SLABS in serious doubt. It is likely a question of when, not if, the SLABS market will collapse, and when it does, private student lending will be crippled, carrying serious negative effects for student borrowers and the colleges they attend. If the 2008 recession was any indication, these developments could happen very quickly and ripple into the rest of the United States' economy, due to the sheer size and scope of student loan debt in relation to overall consumer debt. ${ }^{234}$

\section{CONCLUSION}

Crisis rhetoric is perhaps appropriate to describe the student loan sector, given the staggering proportion of overall consumer debt in the United States accounted for by student loan debt. Yet, student loans are categorically different from other credit products in that-very oftenthey do not require the borrower to fully repay their debt obligation..$^{235}$ That is, a majority of student loans enjoy federal backing and contractu-

student loan relief provided under the CARES Act and noting that it runs until the end of September).

232. Kaufman, supra, note 81 ("The dollar value of private student loans in forbearance exploded, increasing as much as 1360 percent [from January to May of 2020]. . . . Compared to the period prior to the pandemic, the overall number of loans whose borrowers are not making any progress toward repayment increased more than 36 percent." (emphasis omitted)).

233. It seems that judges may have already turned the page on using the bankruptcy process to preclude student loan discharge. See Katy Stech Ferek, Judges Wouldn't Consider Forgiving Crippling Student Loans-Until Now, WALl ST. J. (June 14, 2018, 7:00 AM), https://www.wsj.com/articles/judges-wouldnt-consider-forgiving-crippling-studentloans-until-now-1528974001 [https://perma.cc/NTW5-RJQD] (interviewing more than fifty current and former bankruptcy judges and finding that they are now actively seeking to help debtors, in many cases because they have seen that their law clerks are so heavily mired in student loan debt).

234. See Stein \& Duvall, supra note 14; see also Cox et al., supra note 219; Kenneth Duvall \& Philip R. Stein, COVID-19: What Market Bubbles Will It Burst?, JDSuPRA (Mar. 23, 2020), https://www.jdsupra.com/legalnews/covid-19-what-market-bubbles-will-it-59678/ [https://perma.cc/QF2A-2BYV].

235. See, e.g., John R. Brooks \& Adam J. Levitin, Redesigning Education Finance: How Student Loans Outgrew the "Debt" Paradigm, 109 Geo. L.J. (forthcoming 2020) (describing the uniqueness of student loans' debt forgiveness as being "baked into the student loan product" and arguing that "the economic structure of student loans has evolved to resem- 
ally backed forgiveness features, which most other types of consumer debt-including some types of student loan debt-do not. However, unlike other forms of consumer debt, student loans have historically locked borrowers into full debt obligation repayment by virtue of their virtual nondischargeability in bankruptcy proceedings, which in turn has propped up a robust SLABS market.

It is almost poetic that the same court that handed down the Brunner decision in 1985, which established the virtual prohibition on student loan discharge in bankruptcy proceedings, may be among the handful of courts to begin the work of its undoing thirty-five years later. ${ }^{236}$ The ability to discharge student loans utilizing the existing bankruptcy framework seems to be one obvious solution for mitigating the student loan crisis for borrowers. ${ }^{237}$ Allowing student loan discharge via bankruptcy can potentially offer relief to borrowers who have made an effort to pay back their loans but have been unsuccessful. However, as outlined above, allowing student loan discharge via bankruptcy carries significant costs.

As the national student loan debt figure has climbed, the SLABS industry continued to grow in popularity. Perhaps this result is expected because, when a security presents more like a municipal bond in terms of its surety of return on investment, it is demonstrative of that investment vehicle's stability. But much of the stability of the SLABS industry is built on false premises: the loans backing SLABS are at much greater risk of default than their credit rating would seem to indicate, especially in a post-COVID-19 world, and the general assumption of nondischargeability of student loans in bankruptcy proceedings is in question after the Rosenberg decision and its companion decisions in the federal circuit courts of appeal. Each of these realities makes these "low-risk" investments much risker and points to the possibility that the entire SLABS market could collapse. Besides merely introducing a greater level of risk in the SLABS market, what effect, then, could these developments carry?

Predicting the economic impacts of COVID-19 and the impact of the federal court decisions concluding that student loans are dischargeable in bankruptcy proceedings relies somewhat on speculation, but their potential to disturb the SLABS market, as well as other sectors of the economy, bears due consideration, especially during the present moment of economic uncertainty at the early stages of yet another economic reces-

ble a federal grant program coupled with a progressive income-based tax on recipients, rather than a true debt product").

236. Note that the United States District Court for the Southern District of New York handed down both Brunner v. N.Y. State Higher Educ. Servs. Corp. (In re Brunner), 46 B.R. 752 (Bankr. S.D.N.Y. 1985), aff'd, 831 F.2d 395 (2d Cir. 1987) (per curiam), and Rosenberg v. N.Y. State Higher Educ. Servs. Corp. (In re Rosenberg), 610 B.R. 454, 457 (Bankr. S.D.N.Y. 2020).

237. See, e.g., Zack Friedman, Student Loan Debt Statistics in 2019: A \$1.5 Trillion Crisis, Forbes (Feb. 25, 2019, 8:32 AM), https://www.forbes.com/sites/zackfriedman/2019/02/ 25/student-loan-debt-statistics-2019/\#235d048b133f [https://perma.cc/RC97-QNZT]. 
sion. ${ }^{238}$ However, if the 2008 recession is predictive, it is likely to unfold in a couple of ways. Ultimately, how the recent decisions to permit student loan discharge in bankruptcy could impact the SLABS market and the economy relates to the distinction between secured loans and unsecured loans. Under one possible scenario, similar to the 2008 recession, lenders could be forced to bear the brunt of their losses from student loans discharged in bankruptcy. While accountability can potentially incentivize lenders to use better and safer lending standards, this type of socalled accountability, in the aggregate, leads to deeper economic recessions because financial institutions cannot operate as usual when suffering those types of losses. In this scenario, many borrowers seeking loans may be unable to do so. On the other hand, these recent federal court decisions alone could result in heavy tax consequences for taxpayers in the United States. Student loans are unsecured because many are guaranteed by the federal government. This consequence is analogous to the government bailouts of lenders offering federally backed mortgage programs. ${ }^{239}$ In this scenario, a wave of student loan debts discharged in bankruptcy could potentially result in more government bailouts, with all of the burden on the taxpayers and none of it on the lenders or borrowers. In fact, a recent attempt by the U.S. Department of Education to intercept and seize $\$ 2.2$ billion in tax refunds from student loan borrowers was thwarted in a class-action lawsuit brought by those borrowers, and the refunds were returned to the borrowers. ${ }^{240}$ In effect, the government's attempt to offset its obligations of federal backing by collecting on the loans via government-issued tax refunds demonstrates how tenuous the government's federal-backing guarantee is in the context of student loans. But such a bailout would only protect FFELP loans marketed as SLABS, not the remaining majority of private loans that back SLABS. Thus, SLABS investors could bear considerable losses if a wave of private student-loan borrowers default.

In either event, the weight of the Rosenberg ruling, and those like it in the federal circuit courts of appeal, may ultimately contribute to the collapse of the SLABS market. Just three months into the COVID-19 pan-

238. Alan Rappeport \& Jeanna Smialek, I.M.F. Predicts Worst Downturn Since the Great Depression, N.Y. Times (June 24, 2020), https://www.nytimes.com/2020/04/14/us/ politics/coronavirus-economy-recession-depression.html [https://perma.cc/Q25Q-4VB2]; Elizabeth Schulze, The Coronavirus Recession Is Unlike Any Economic Downturn in US History, CNBC (Apr. 8, 2020, 12:33 PM), https://www.cnbc.com/2020/04/08/coronavirus-recession-is-unlike-any-economic-downturn-in-us-history.html [https://perma.cc/Z8SCGVH5].

239. Federally-backed mortgage programs include options to obtain mortgages through the Federal Housing Administration, Fannie Mae, Freddie Mac, etc. However, the majority of mortgages are not federally-backed and are available through private lenders.

240. Despite the fact that the collection of student loans was expressly prohibited under the CARES Act, the U.S. Department of Education has admitted to offsetting more than one million student loan borrowers' tax refunds in the middle of the pandemic. See, e.g., Adam S. Minsky, Dept. of Education Discloses Illegal Seizure of \$2.2 Billion from Student Loan Borrowers, Forbes (June 1, 2020, 2:41 PM), https://www.forbes.com/sites/adamminsky/2020/06/01/dept-of-education-discloses-illegal-seizure-of-22-billion-from-student-loanborrowers/\#7568c1d05ede [https://perma.cc/8FPN-VMWK]. 
demic, many borrowers who have made good faith efforts to repay their loans have found that their expenses exceed their income. They have entered forbearance or delinquency, which will ultimately lead to default. When more borrowers become able to discharge their student loans in bankruptcy, the basis upon which the entire SLABS market is premised-i.e., low-risk investments due to nondischargeability of loans through bankruptcy proceedings-fails. Thus, the risk level associated with SLABS will undoubtedly increase if it has not risen already.

In response to the COVID-19 pandemic, all student loan paymentson both principal balance and interest-were suspended through December $31,2020 .{ }^{241}$ But this relief is temporary and quickly reaching its termination date. In April 2020, 20.5 million jobs were lost and, as a result, the national unemployment rate jumped to $14.7 \%$, the highest unemployment rate since the Great Depression. ${ }^{242}$ Increased unemployment rates will foreseeably lead to an increased likelihood that a multitude of borrowers will begin having trouble repaying their student loans. Without employment prospects or steady earnings, many of these borrowers could default on their student loans, ultimately need to file for bankruptcy, and may have their student loan debts discharged. Although nothing is certain in these uncertain times, it is increasingly difficult to shake the feeling that history will repeat itself in just twelve years' time. If it does, the student loan debt crisis could have greater meaning — not just for individual borrowers, but for the American taxpayer, for the SLABS investor, and for the American economy as well.

241. See, e.g., Information for Student Loan Borrowers, Consumer Fin. Prot. BuREAU, https://www.consumerfinance.gov/coronavirus/student-loans/ [https://perma.cc/ DU9N-JM86]. While there is support for extending student loan debt relief through 2021, it remains to be seen. See Wesley Whistle, Higher Education Groups Call for Extended Student Debt Relief, Forbes (Apr. 20, 2020, 5:04 PM), https://www.forbes.com/sites/wesleywhistle/2020/04/20/higher-education-associations-call-for-extended-student-debt-relief/? ss=education\#70fa062d3dc4 [https://perma.cc/JM2K-NGYX].

242. See, e.g., Nelson D. Schwartz, Ben Casselman \& Ella Koeze, How Bad Is Unemployment? 'Literally Off the Charts', N.Y. Times (May 8, 2020), https://www.nytimes.com/ interactive/2020/05/08/business/economy/april-jobs-report.html [https://perma.cc/AV8YB4K8]. 
